University of Rhode Island

DigitalCommons@URI

Open Access Master's Theses

1970

\title{
Some Economic Planning Considerations of Ground Water Pollution for the Upper Pawcatuck River Basin in Rhode Island
}

Arnold Joseph Antak

University of Rhode Island

Follow this and additional works at: https://digitalcommons.uri.edu/theses

\section{Recommended Citation}

Antak, Arnold Joseph, "Some Economic Planning Considerations of Ground Water Pollution for the Upper Pawcatuck River Basin in Rhode Island" (1970). Open Access Master's Theses. Paper 1357.

https://digitalcommons.uri.edu/theses/1357

This Thesis is brought to you for free and open access by DigitalCommons@URI. It has been accepted for inclusion in Open Access Master's Theses by an authorized administrator of DigitalCommons@URI. For more information, please contact digitalcommons-group@uri.edu. 
SOME ECONOMIC PLANNING CONSTDERATIONS OF

GROUND WATER POLLUTION FOR THE:

UPPER PAWCATUCK RIVER BASIN

IN RHODE ISLAND

BY

ARNOLD JOSEPH ANTAK

A THESIS SUBNITTED IN PARTIAL FULFILLMENT OF THE REQUIREMENTS FOR THE DEGREE OF

MASTER OF COMMUNITY PLANNING

UNIVERSITY OF RHODE ISLAND

1970 
MASTER OF COMMUNITY PLANNING THESIS

$\mathrm{OF}$

ARNOLD JOSEPH ANTAK

Approved:

Thesis Conmittee:

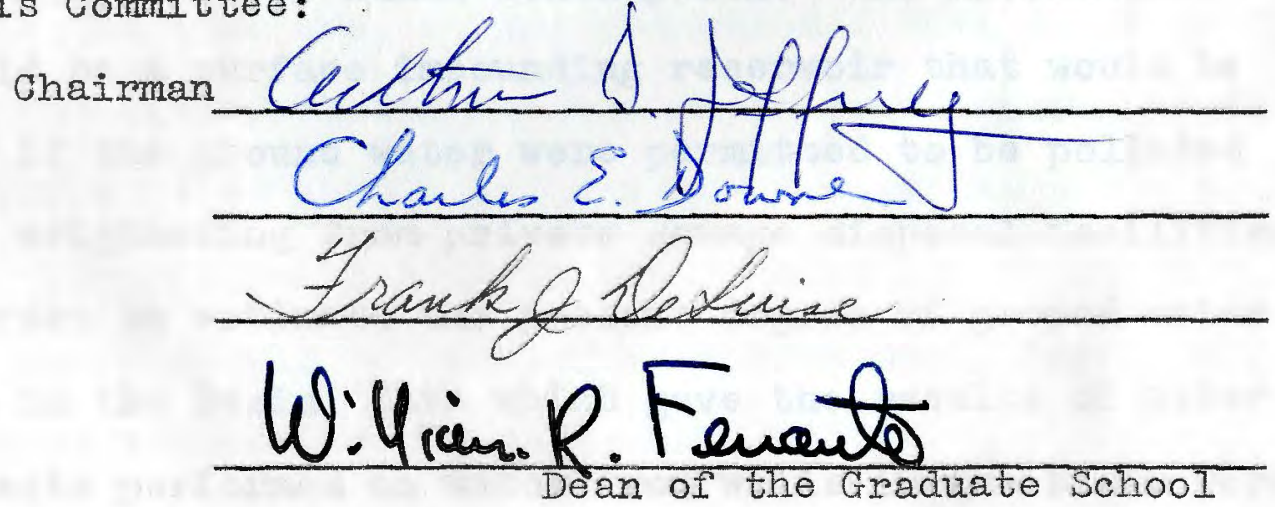

UNIVERSITY OF RHODE ISLAND 


\section{ABSTRACT}

This study was concemed with the economics of supplying an area with water suitable for human consumption. The area chosen for study was the Upper Pawcatuck River Basin in Rhode Island, which has the largest ground water reservoirs in the state. Since the people within and adjacent to the Basin depend exclusively on water from these ground water reservoirs, this study investigated a means of preserving the quality of the ground water so that other methods of supplying water, which might be more costly, would not have to be developed. These other methods would be necessary if the ground water were allowed to become polluted.

The hypothesis tested in this study was that the costs involved in developing a regional sewage treatment and disposal system, together with a large scale muicipal well development, are less than the development costs of an alternative means of supplying water for human consumption. The alternative means would be a surface impounding reservoir that would be necessary if the ground water were permitted to be polluted by sewage originating from private sewage disposal facilities.

In order to estimate the present degree of ground water pollution in the Basin, data which gave the results of water quality tests performed on water from wells in the Basin were obtained from the Rhode Island Department of Health. It was 
found that although a serious widespread ground water pollution problem does not exist at the present time, the potential for areawide pollution problems in the future is present. A means of eliminating this potential was proposed to be the development of a regional sewage treatment and disposal system to eliminate the necessity of private sewage disposal systems (septic tanks and cesspools).

In order to test the hypothesis, cost data were obtained from various sources in order to estimate the development costs of a regional sewage treatment and disposal system, a municipal ground water development, and a surface impounding reservoir. It was found that the development costs of a municipal ground water development together with a regional sewage treatment and disposal system were less than the development costs of a surface impounding reservoir that would yield approximately the same amount of water.

Dre to economic benefits and the effect that the provision of water supply and sewage disposal facilities has on land development and use, it was recommended that planning for these facilities should be done on a comprehensive basis that considers water supply and sewage disposal as a single function. The planner's role in the formulation of water and sewer plans should be that of an active participant and not merely an advisor to the engineer. 


\section{ACKNOWLEDGMENTS}

The author wishes to express his appreciation to

Doctor Arthur D. Jeffrey, Professor of Economic Development and Regional Planning, for his valuable assistance during the preparation of this manuscript. Special thanks are also extended to Assistant Professor Charles E. Downe and Associate Professor Frank J. Deluise for their helpful suggestions and comments.

The cooperation of various individuals concerned with water supply and pollution control in the state of Rhode Island is also gratefully acknowledged. Those who were especially helpful were Mr. John Clifford of the Rhode Island Department of Health, Division of Water Supply Control, and Mr. Henry Monroe of the Rhode Island Water Resources Board.

Appreciation is also extended to Mr. Kenneth Gminski who typed the first draft and to Miss Helen Palmer who typed the final manuscript. 
TABLE OF CONTENTS

CHAPTER

PAGE

I. INTRODUCTION. . . . . . . . . . . . . . I

Water in General. . . . . . . . . . . I

The Hydrologic Gycle. . . . . . . . . 3

Supply of Water in the U.S. . . . . . . . 4

Water Use in the U.S. . . . . . . . . . 6

Importance of Ground Water in the National

Water Situation. . . . . ...... 8

Ground Water Use in the U.S......... . 8

Supply of Water in R.I. . . . . . . . . . 11

Water Use in R.I. . . . . . . . . . 13

Ground Water Location in R.I. . . . . . . 14

Role of Ground Water in the R.I. Water

Situation............ . 15

The Conservation of Ground Water. . . . . 18

II. DESCRIPTION OF THE UPPER PAWCATUCK RIVER BASIN. - $2 I$

Location. . . . . . . . . . . . 21

Geohydrologic System. . . . . . . . 23

Hydrology . . . . . . . . . . . . 24

III. GROUND WATER IN THE UPPER PAWCATUCK RIVER

BASIN. . . . . . . . . . . . . 27

Ground Water Potentially Available for

Development. . . . . . . . . 27

Importance of Ground Water to the Area. . . . 30 
CHAPTER

PAGE

IV. POLLUTION OF GROUND WATER . . . . . . . . 40

Causes of Pollution of Ground Water. . . . . 40

Pollution of Ground Water in the U.S. . . . . 4 I

Water Quality Analysis. . . . . . . . 42

Chemical Constituents........ 43

Pollution of Ground Water by Synthetic

Detergents.......... . 43

Pollution by Chlorides. . . . . . . 46

Pollution by Nitrogen Matter. . . . . 47

Physical Characteristics of Ground Water. . 48

Bacterial Pollution . . . . . . . 48

V. MOVEMENT OF POLLUTANTS. . . . . . . . . . 50

Movement in the Zone of Aeration. . . . . . 51

Movement in the zone of Saturation. . . . . 52

VI. POLLUTION OF GROUND WATER IN THE UPPER

PAWCATUCK RIVER BASIN. . . . . . . . 55

The R.I. Department of Health Water Analysis. . 55

Analysis of Private Well Data . . . . . . 57

Overall Safety of the Water Supply for

Human Consumption. ........ 59

Bacteriological Examination Conclusions . . 60

Chemical Examination Conclusions. . . . 60

Physical Characteristics. . . . . . . 61

Imperfections in Construction and/or Place-

ment of Well and/or Disposal System. . . 6I

Analysis of Public Well Data. . . . . . . 63

Surmary and Conclusions . . . . . . . 65 
VII. DEVELOPMENT COSTS OF SEWAGE DISPOSAL AND WATER SUPPLY FACILITIES. . . . . . . . 68

Inadequacy of Private Sewage Disposal Facilities . . . . . . . . . . 69

Development Costs of a Regional Sewage Treatment and Disposal System. . . . . 72

Development Costs of a Large Scale Ground Water Supply ........... . 76 Development Costs of a Surface Water Supply . . 80 Comparison of Development Costs...... 82 VIII. PLANNING IMPLICATIONS . . . . . . . . . . 90 Problems at the Local Level . . . . . . . 91 Overview of Benefit-Cost Analysis . . . . . 96 Comprehensive Planning for Water Supply and Sewage Disposal. . . . . . . . . 102 BIBLIOGRAPHY. . . . . . . . . . . . 105 APPENDIX. . . . . . . . . . . . . . . . 109 
LIST OF TABLES

TABLE

PAGE

1. Summary of Water Uses for the Conterminous U.S.. . 7

2. Projections of Ground Water Use in the U.S.... 10

3. Ground Water Purmage in the U.S. . . . . . . . 11

4. Current Withdrawal from Ground Water Basins in R.I................. 16

5. Water Systems in the Upper Pawcatuck River Basin and Demands . . . . . . . . . 32

6. Pumpage by the Wakefield Water Company . . . . 33

7. Projected Population of South Kingstown. . . . 35

8. Projected Population and Corresponding Per Capita Consumption Rates Based on a 1.5 Gallons Per Capita Per Year Increase for South Kingstown . . . . . . . . . 36

9. Causes of Deterioration of Ground Water Quality. . 40

10. Limits of Concentrations of Chemical Substances Where Other More Suitable Water Supplies Are or Can Be Made Avallable.......... 44

11. Limits of Concentration of Chemical Substances that Constitute Ground for Rejection of a Water Supply. . . . . . . . . . . 44

12. Drinking Water Physical Characteristics Standards ............. 48

13. Examples of Distance and Time of Travel of Various Types of Pollutants... . . . . . 54

14. System Cost Itemization for a Combined Sewage Treatment and Disposal System for Narragansett, South Kingstown, and the University of Rhode Island. 
15. Estimates of Sewered Population and Average Flow for Part of the Tlown of South Kingstown and the University of Rhode Island. . . . . 77

16. Development Costs of a 1.6 MGD Well System



17. Probable Initial Development Costs Associated with a 25 MGD WeIl Development in the Upper Pawcatuck River Basin . . . . . . . . 79

18. Development Costs Associated with the Big River Surface Impounding Reservoir. . . . . . . 81

19. Updated System Cost Itemization for a Combined Sewage Treatment and Disposal System for Narragansett, South Kingstown, and the University of Rhode Island. ......... 83

20. Updated Probable Initial Development Costs Associated with a 25 MGD Well Development in the Upper Pawcatuck River Basin....... 84

21. Updated Development Costs Associated with the Big River Surface Impounding Reservoir. . . . 86

22. Cost Comparison Between Development Costs of the Upper Pawcatuck River Basin Ground Water Supply and the Big River Reservoir Surface Supply. . . . . . . . . . . . 87

23. Estimated Units Cost of Construction, Operation and Maintenance of Sewage Works Facilities. . 103 
LIST OF FIGURES

PIGURE

PAGE

1. Location of Ground Water Basins in R.I.. . . . . 17

2. Regional Location of the Upper Pawcatuck River

Basin in R.I. ............. 22

3. Relation of Annual Water Loss to Air Temperature

in Humid Areas. . . . . . . . . . . 26

4. Location of Ground Water Reservoirs. . . . . 28

5. Relationship between Years and Average Daily

Pumpage of Ground Water by the Wakefield

Water Company ............ . 34

6. Phases of Movement for Pollutants. . . . . . 50

7. Private On-Lot Sewerage Systems. . . . . . 70

8. Public Sewage System Diagram . . . . . . . 74 
INTRODUCTION

Water in General

When the United States is considered in total, there is no doubt that the country possesses an abundance of the natural resource called "water". The average annual rainfall in the United States for many years has been about 30 inches. This 30 inches of rainfall is equivalent to an average of 4,400 billion gallons of water per day of which about $14 \%$ or approximately 600 billion gallons por day (bgd) is usable. ${ }^{1}$ This usable water is obtained from both surface and underground supplies.

The fact that the country has an ample supply of water to meet total demands at the present time and for some time in the future does not mean that there are no problems associated with this valuable resource. First, it must be realized that the total quantity of water is constant. Therefore, population growth and an increased rate of consumption will increase the demand for water, while the total supply romains constant.

All problems of water supply are basically ones of quantity and quality. As more and more people occupy a particular erea and as per capita consumption is increased

${ }^{1}$ U.S. Congress, Senate, Select Committee on National Water Resources, Water Resource Activities in the United States: Future Water Requirements for Kunicipal Use, 86th Cong., 2d Sess., 1960, Committee Print No. 7, p. 9. 
due to a higher standard of living and to technological devices that make increased use of water necessary for their functioning, the question of quantity becomes a major fretor. Furthermore, the actual amount of water available in various parts of the country may vary widely. If the quantity of water is scarce in a region and transporting it to the region involves enormous costs, then the region cannot support very much human habitation, and the chances for growth are very small.

Although the actual amount of water in a region may vary by location and through time and also by the use man makes of the supply, concern must also bo given to the quality of water, since quality determines the uses that will be made of the water. At the present time the question of water quality must be given more serious attention than water quantity. The fact that the peoplo of the United States are using only a small percentage of the amount of water actually vailable for use, and also because an increasing amount of water is being roused, there appoars no need for alarm that the country as a whole is heading toward a water shortage. On the other hand, water quality has become a serious problem for if water is to be suitable for reuse, it must be free of harmful substances. Industrial use of water, the increased use of detergents, unsuitable private waste disposal systems, and the inadequacy and lack of sewage disposal facilities have threatened and in many cases lessened or destroyed the quality of many water supplies. 
Afe Hyarologic Cycle

Water is considered a renewable resource because the supply at any place and at any time is dependent upon what is known as the hydrologic cycle. Through this cycle, the exchange of water between the earth and the atmosphere is effected by the heat of the sun and the force of gravity. The hydrologic eycle describes the circulation of water from the ocean, to the atmosphere, to the land, and back to the ocean.

If it is assumed that the hydrologie eycle begins at the ocean, all usable water has its origin in the ocean, where it ultimately returns after proceding through the hydrologic cycle. When the sun heats the water in the ocean, evaporation occurs and thus places water in the atmosphere. The process of evaporation may also occur from water found in ponds, lakes, and streams, and also from ground water in areas where the water level is very close to the surface of the land. Water may also proceed through the process of transpiration. The two processes of evaporation and transpiration are commonly grouped together and referred to as the process of evapotranspiration.

Another phase of the hydrologic cycle is precipitation. Precipitation occurs when water vapor in the atmosphere is condensed. The air temperature is the controlling factor as to the amount of water vapor which the atmosphere can carry without loss by condensation. Procipitation occurs when moist air cools to the point when there is too much 
water for the atmosphere to hold as vapor. When this occurs, some of the vapor changes to liquid water which falls due to the force of gravity.

The water that reaches land as precipitation may follow a number of courses. It may run off into stroams, be discharged by evapotranspiration, or be stored underground. Ranoff consists of water that falls directly on the streams or runs over the land surface to them, and water that moves below the ground surface and discharges into the streams. In areas where there is an abundance of rainfall, the water which reaches underground strata known as "aquifers" represents a large portion of the supply available for human use. In addition to the water that is confined, some water found in these aquifers is not static but flows to areas of natural discharge such as springs, ponds and lakes, swamps, and wells.

In analyzing and planning for the water needs of an area, attention must be given to all phases of the hydrologic cycle. Although this study is primarily concerned with ground water, the complexities of the hydrologic cycle indicate that no single phase of the cycle can be entirely divorced from the others.

Supply of Water in the United States

The amount of water available for human use in the United States is the same as the total moff plus underground storage. Since total runoff and underground storage are determined by the amount of precipitation that falls on the earth, it can be said that the United States has an abundant 
supply of water. An average of about 30 inches of water in the form of rain and snow reaches the United States each Jear. This 30 inches of precipitation represents about 4,900 million acre-feet or about 4,400 billion gallons of water per day. ${ }^{2}$ The total rain that falls on the United States in a day was qual to approximately 22,000 gallons of water each day for each man, woman, and child living in the United States in $1965 .^{3}$ Thus, although there are dry Jears and wet years, this 22,000 gallons per capita per day seems more than adequate for both present and future needs. A supply of 4,400 billion gallons of water per day seems immense; however, there are factors that make it possible to retain only $14 \%$ of this water for human use. First, more than two-thirds of the water that reaches the earth returns to the atmosphere through evaporation and transpiration from plants. Of the water that is rotained, problems also arise due to such factors as oxcessive mineral content and pollution by biological and chomical vastes.

The major problem concerned with the quantity of water in the United States is that the 30 inches of annual rainfall on the United States is not equally distributed. Although the United States as a nation has a sufficient quantity of water to meet present and future needs, the

${ }^{2}$ C.L. MeGuinness, The Role of Ground Water in the National Water Situation, Geological Survey Water-Supply Paper 1800 (Washington: United States Geological Survey, 1963), p. 10.

Water in Industry (New York: National Association of Manufacturers, 1965), p. 4 . 
irrogular distribution of water over the country does not guarante an adequate supply for all areas. From an economic viewpoint, any area that is lacking an adequate supply of water may obtain water from somewhere else if it is willing to pay the necessary cost of obtaining this water. However, the price in many cases may be too high for an area to bear.

Water Use in the United States

The use of water can be placed into two categories: consumptive use and non-consumptive use. Consumptive use refers to the use of water resulting in a large proportion of the water being lost to the atmosphere by evapotranspiration or being used in such a manner that the quality of the water is lessened to the degree that it cannot be used for any other purpose. An example of this type of use is irrigation, since irrigation water evaporates and transpires to the atmosphere or percolates into the subsoil. Non-consumptive use refers to a use of water that allows it to remain readily available for future use. Non-consumptive uses return water to a stream or to the ground in approximately the same quantity and quality as it was used previously.

The Senate Select Committee on National Water Resources in 1960 studied the use of water in the United States and also made projections of water use into the future.4 Table 1 shows the Senate's findings and projections of water use in the United States for the years 1980 and 2000.

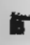

$4^{4}$ U. S. Congress, Senate, Select Comittee on National Water Resources, Water Resource Activities in the United States: Water Supply and Demand, 86 th Cong., 2d Sess., 1960, Committee Print No. 32, p. 4 . 
TABLE I

SUMMARY OF WATER USES FOR THE CONTERMINOUS UNITED STATES (BILLIONS OF GALLONS PER DAY)

\begin{tabular}{|c|c|c|c|c|c|c|}
\hline \multirow[b]{2}{*}{ Use } & \multicolumn{2}{|c|}{1954} & \multicolumn{2}{|c|}{1980} & \multicolumn{2}{|c|}{2000} \\
\hline & $\begin{array}{l}\text { With- } \\
\text { drawal }\end{array}$ & $\begin{array}{l}\text { fonsump- } \\
\text { tive use }\end{array}$ & $\begin{array}{l}\text { With- } \\
\text { drawal }\end{array}$ & $\begin{array}{l}\text { Consump- } \\
\text { tive use }\end{array}$ & $\begin{array}{l}\text { With- } \\
\text { drawal }\end{array}$ & $\begin{array}{l}\text { Consump- } \\
\text { tive use }\end{array}$ \\
\hline Municipal & 16.7 & 2.1 & 28.6 & 3.7 & 42.2 & 5.5 \\
\hline Agricultural & 176.1 & 103.9 & 167.2 & 104.5 & 184.2 & 126.3 \\
\hline Manufacturing & 31.9 & 2.8 & 101.6 & 8.7 & 229.2 & 20.8 \\
\hline Steam Electric & 74.1 & 0.4 & 258.9 & 1.7 & 429.4 & 2.9 \\
\hline Mining & 1.5 & 0.3 & 2.7 & 0.6 & 3.4 & 0.7 \\
\hline Total & $300 \cdot 3$ & 109.5 & 559.0 & 119.2 & 888.4 & 156.2 \\
\hline
\end{tabular}

Source: Senate Select Comittee on National Water Resources

The projections that the Senate Conmittee made were based on the following assumptions: (1) that population and the national economy will continue to grow at past rates, (2) that adequate water supplies will be made available under present pricing policies, (3) that there will be little change in presently known technical methods of water use, and (4) that present inefficient methods of water use will continue except that irrigation efficienoy will improve substantially. Although the author feels that the last two assumptions may not be entirely valid, in order for the Committee to make some kind of projections for the future, these assumptions were necessary. 
Another major assumption made by the Senate Comittee was that there will be a great increase in the use of ground water as a source of supply. As present surface supplies are strained more and more, and as the cost of developing and transmitting surface water increases, ground water will grow in importance in the national water situation.

Spertance of Ground Water in the National Water Situation

As mentioned earlier, ground water is just one phase of the hydrologic eycle. It can be found wherever and whenever openings below the surface are filled with water under hydrostatic pressure, and ground water moves whenever gravitational forces are great enough to overcome the forces of friction. The fact that ground water is so abundant throughout the country has enabled people to occupy areas that otherwise could not have been settled.

Ground water as a source of supply has definite advantages. First, it has a constant temperature that comes very elose to the average air temperature. In addition, the quality of the water is consistent, and it usually is free of harmful bacteria. Evaporation occurs to a much smaller degree than in surface water. Also, wells can be installed at the place and time at which water is needed.

Ground Water Use in the United States

Throughout the United States, there has been relatively Iittle development and use of ground water. In 1955, total ground water use amounted to 46,350 million gallons per day 
(mgd). However, the ratio of ground water use to total water use amounted to only 19\%. The state of California had the highest ratio of ground water use to total water use at $36 \%$, while the District of Columbia only had a ratio of $3 \%$. Rhode Island, as of 1955, had a ratio of only $6 \%$ of ground water use to total water use. 5

The reason for the very small use of ground water has been the lack of knowledge associated with this valuable resource. As more information is obtained about ground water, its value as a source of supply can be expected to increase. The main problem in the past has been that the actual amount of water available below the ground was not accurately known. However, the U.S. Geological survey, together with many state and local organizations, has been conducting extensive tests and studies concerning ground water.

Although it is very difficult to measure ground water withdrawal on a nation-wide basis, estimates have been made. Based on the studies conducted by the U.S. Geological Survey, ground water withdrawal amounted to approximately $30 \mathrm{bgd}$ in 1950.6 One decade later, in 1960, total ground water withdrawal had increased to about $47 \mathrm{bgd} .7$

5K.A. MacKichan, "Estimated Use of Water in the United States, 1955", Journal of the American Water Works Association, v01. 49 (1957), pp. 369-391.

${ }^{6}$ K.A. MacKichan, Estimated Use of Water in the United States, 1950 , U.S. Geological Survey Circular 115 (Washington: U.S. Geological Survey, 1951).

7K.A. MacKichan and J.C. Kammerer, Estimated Use of Water in the United States, 1960 , U.S. Geological Survey Circular 456 (Washington: U.S. Geological Survey, 1961). 
There seems to be little doubt that the use of ground water will continue to increase in the future. As more knowledge and data are obtained for various areas in the United States concerning ground water, as the number of potential surface reservoir sites is diminished, and as the cost of transmitting surface water to developing suburban areas increases, ground water will increase in importance as a source of supply.

\section{TABLE 2}

PROJECTIONS OF GROUND WATER USE IN THE UNITED STATES

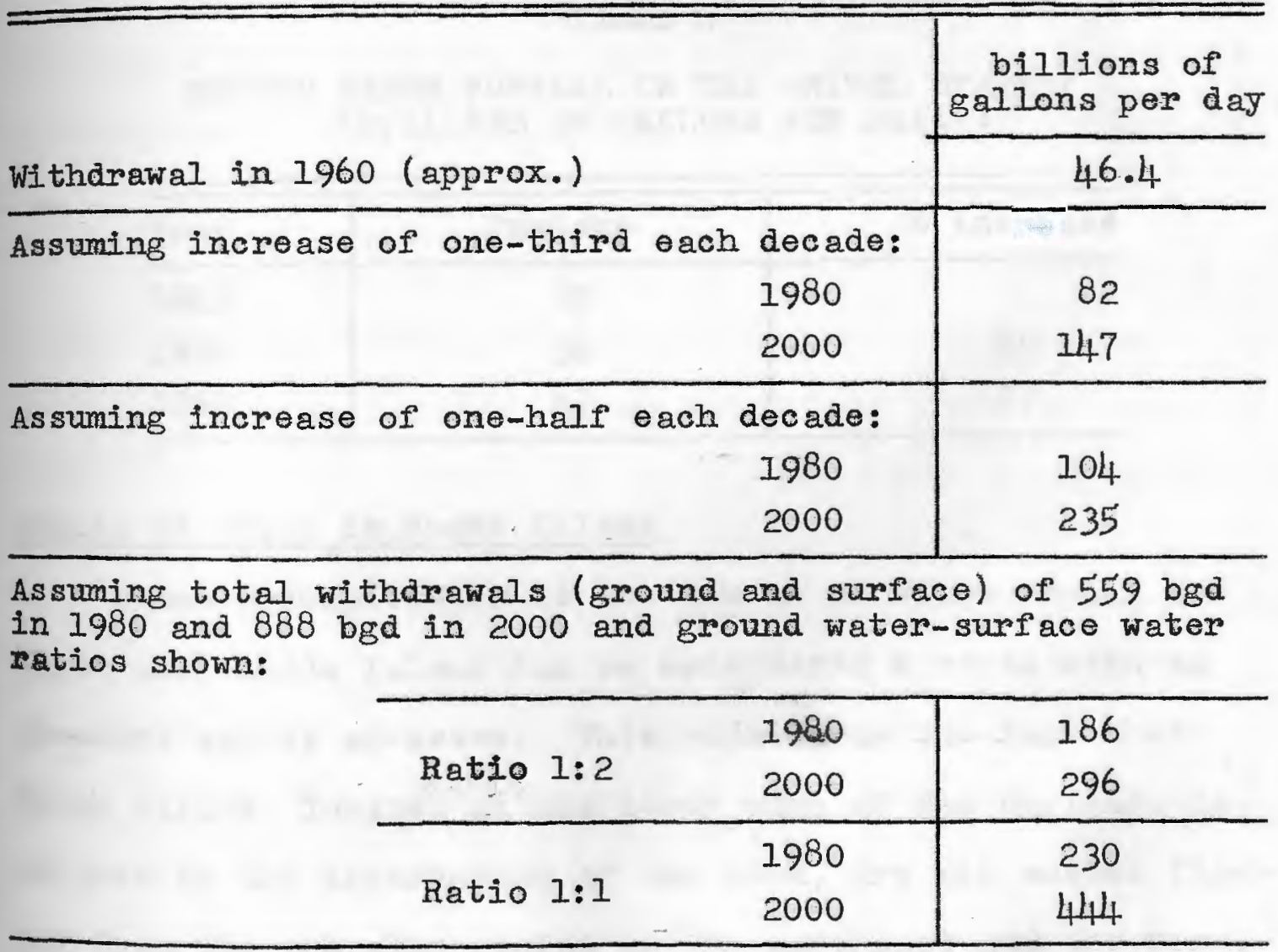

Source: Senate Select Comittee on National Water Resources 
The Senate Select Committee on National Water Resources has predicted the levels of ground water withdrawal for the years 1980 and 2000.8 Table 2 shows the predictions that the Senate Committee had made, based on the assumptions given previously.

The assumption made by the Senate Committee that the withdrawal of ground water will increase by one-third to - ne-half each decade appears to be a valid one. By looking at the pumpage of ground water for past years, it can be seen that the Senate Conmitteo's predictions may be reached.

\section{TABLE 3}

GROUND WATER PUNPAGE IN THE UNITED STATES 9 (BILLIONS OF GALLONS PER DAY)

\begin{tabular}{l|c|c}
\hline Year & Pumpage & \% increase \\
\hline 1945 & 20 & \\
1950 & 30 & 50 \\
1960 & 47 & 57 \\
\hline
\end{tabular}

Sapply of Water in Rhode. Island

Since precipitation is the source of water supply for humen use, Rhode Island can be considered a state with an abundant supply of water. This stems from the fact that Rhode Island, located at the lower edge of New Fngland, is subject to the interaction of the cold, dry air masses flowing from the subpolar region to the northwest and the warm, tropical air from the south. This interaction produces an

${ }^{8}$ J.S. Congress, Senate, Select Committee on National Water Resources, Committee Print No. 32, op. cit.

9 MeGuinness, op. cit., preface. 
average annual precipitation of approximately 42 inches. 10 This Iigure is far above the national average of about 30 inches per year and is more significant from the fact that one inch of rain over any area of one square mile is equivalent to 17 million gallons of water. 11

In addition to the favorable amount of precipitation, the topography and geology of Rhode Island are conducive to periding an abundant supply of water. The western upland areas of the state produce slow runoff, while the lowlands in the area of Narragansett Bay are very favorable to the storage of ground water. Because of its physical characteristics and precipitation, Rhode Island has an average jield of water per square mile that is three times the average for the United States. 12

When considering the supply of water available in Rhode Island, attention must be given to both the surface and ground supplies. In 1965, approximately $25 \%$ of the state's area or 304 square miles, and $65 \%$ of the state's population or 580,000 people were served by surface waters. ${ }^{13}$

${ }^{10}$ B.K. Harris and T.E. OdIand, Rhode Island Weather, Bulletin of the R.I. Agrieultural Experiment Station 和ingston: R.I. Agr. Exp. Sta., 1948), p. 15.

II A Water Resources Program for Rhode Island, Water Re sources Memorandum No. 3 (Providence: Rhode Island Porelopment Council, 1954), n.p.

$12_{\text {Ibid. }}$

13 Preliminary PIan for Public Water Supply and Distribution, (Providence: R.I. Statewide Comprehensive Transportation and Land Use Planning Program, 1969), p. 11. 
The total amount of ground water available for development in Rhode Island is a very difficult item to determine. Various studies conducted by the U.S. Geological Survey and the R.I. Water Resources Goordinating Board have shown that substantial amounts of ground water deposits do exist; however, until further tests and studies are made the exact amount available in the state cannot be accurately determined. One area for which extensive tests have been conducted is the Upper Pawcatuck River Basin located in the southern part of the state. Mr. W. J. Shea, former chairman of the Rhode Island Water Resources Coordinating Board, has estimated the safe yield of surface and ground water supplies at $154 \mathrm{mgd}$ as of $1957,165 \mathrm{mgd}$ as of 1960 , and $168 \mathrm{mgd}$ as of 1961.14

\section{Water Use in Phode Island}

Statistics on the use of water in Rhode Island have been compiled by the R.I. Statewide Comprehensive Transportation and Land Use Planning Program. ${ }^{15}$ Water withdrawn from the major public and institutional water systems of the state amounted to $102 \mathrm{mgd}$ in 1965. About $50 \mathrm{mgd}$ was used by industry, while the remaining 52 mgd was withdrawn for residential and comercial use and fire fighting, recreation, and other micipal uses.

About $35.5 \mathrm{mgd}$ of non-public supplied water was used by Industry in Rhode Island in 1965. Of this $35.5 \mathrm{mgd}$, approximately $16.5 \mathrm{mgd}$ was ground water, while the remaining $19.0 \mathrm{mgd}$ $14_{\text {MeGuinness, op. cit., p. } 761 .}$

15. R. Statewide Comprehonsive Transportation and Land Use Planning Program, op. cit., pp. 15-18. 
came from surface sources. These figures do not account for the use of water by small industries that were not included in the survey. These small industries may have used an aditional $20 \mathrm{mgd}$, giving a total of about $55.5 \mathrm{mgd}$ of an-public water consumed by industry.

It was estimated that less than $10 \mathrm{mgd}$ was used for Irrigational purposes in 1965. Most of this non-public irrigational use occurred in the potato growing area located in the southern part of the state. In 1965, approximately $3.5 \mathrm{mgd}$ of non-public water consumption was devoted to residential use. This figure was arrived at by applying a 50 gallon per capita per day allowance to the 70,000 people in Rhode Island who were not served by the major public or institutional water systems.

Teund Water Location and Use in Rhode Island

The surficial deposits found in Rhode Island which yield ground water are outwash and till. Outwash deposits are composed of well-sorted sands and gravels and are the principal water yielding deposits. On the other hand, till is an unsorted mixture of boulders and cobbles and generally yields water slowly to wells.

The ground water reservoirs in Rhode Island are supplied with water by (I) precipitation falling directly on the outwash deposits, (2) underflow from surrounding till, (3) leakage from swamp deposits and small channel storage, and (4) direct infiltration from streams crossing the outwash 
bodies. 16 water is diverted from the underground reservoirs by the streams that drain the outwash deposits. These streams obtain a portion of their yearly flow and all of their dry weather flow from ground water.

Withdrawal use of ground water in the state of Rhode Island has been minimal. Table 4 is a listing of the estimated current withdrawal of ground water for the various river basins and areas in the state. Figure 1 shows the location of the river basins and ground water areas in Rhode Island. 17 The numbers on Figure 1 correspond to the basins enumerated in Table 4.

The total withdrawal of ground water of $44.7 \mathrm{mgd}$ represents but $20 \%$ of the estimated pumping capacity. ${ }^{18}$ The pumping capacity is not the total amount of ground water available, but rather is defined as an estimate of the ground water that would be available if the low flow in the streams and rivers is to be maintained.

20 of Ground Water in the R.I. Water Situation

Although ground water is not being used extensively in the state at the present time, planning for the water supply needs of areas in the state must consider ground water as a source of supply. Tests and studies from the U.S. Geological

16 Report to the Water Resources Coordinating Board, State of Rhode Island, on a Development Plan for the Water Supply Resources of Rhode Island (Boston: Metcalf and Eddy, Engineers, 7), p. E-4.
17
Ibid., p. E-I4.
18
Ibid., p. E-12. 
Survey show that there are several areas in the state capable of providing significant supplies of ground water.

TABLE 4

CURRENT WITHDRAWAL FROM GROUND WATER

BASINS IN RHODE ISIAND

Ground Water Basin

Current wi thdrawal in $\mathrm{mgd}$

1. Upper Branch River

2. North Smithfield-Woonsocket Area

3. Blackstone River Area

4. Upper Woonasquatucket River Area

5. Providence-Warwick Area

6. Pawtucket-East Providence Area

7. Barrington-Warren Area

8. Quinebaug River Area

9. North Branch Pawtuxet River Basin

10. South Branch Pawtuxet River Basin

11. Potowomat-Wickford area

12. Upper Pawcatuck River Basin

13. Wood-Pawcatuck Area

14. Lower Pawcatuck River Basin

15. South Coastal Area

16. Eastern Bay Area

17. Block Island

1.5

1.0

6.8

1.0

8.0

3.0

2.0

0.5

0.5

3.1

6.6

3.9

1.0

3.4

0.5

1.8

0.1

Total withdrawal

44.7

Source: Metcalf and Eddy, Engineers, 1967

There exists the great possibility of using ground water to supplement surface supplies. For example, many industries could tap their own underground wells and thus would not have to obtain water from public reservoir supplies. If this were done, the water from public supplies not used by industry would become available to other users. 
The predicted growth of water supply requirements for the state indicates that an additional $75 \mathrm{mgd}$ may be needed in 1990 and $149 \mathrm{mgd}$ above the 1965 public water supply quirement of $93 \mathrm{mgd}$ may be needed in the year 2020.19 It is possible that ground water could be used on an thereased scale to satisfy the future water demands of the state because of its widespread availability and of the pelatively low cost of development and treatment of the water. The large capability for storage in many ground water reservoirs is the major factor favoring increased ground water development. Storage in underground reservoirs can be utilized in places where surface storage is impractical because of economic reasons. These economic reasons may be the large expense of dam construction or the loss of valuable land that must be flooded for a surface reservoir.

The Conservation of Ground Water

Once the potential value of ground water is understood, knowledge must be sought concerning the ways water is put Into the ground and taken out, as well as the effect man's activities may have on this natural resource. Although ground water development offers great potential in providing an adequate supply of water for the future, the danger of abusing this resource is also present.

A problem may occur when the situation arises in which natural replenishment is inadequate to meet the demand for 
ground water. According to the U.S. Geological Survey, there is one area of the state where this problem may occur in the inmediate future. This area is located in central Rhode Island. It is known as the Potowomut-Wickford area and includes East Greenwich in Kent County and North Kingstown in Washington County. 20 This is an area of increasing development, and steps may be necessary to regulate the amount of ground water withdrawn in the future. A cotinuation of present pumping rates may cause salt water to be drawn into the reservoir or may even eventually empty the ground water reservoir if conservation measures are not taken.

In areas where natural replenishment is adequate for present uses, other problems may occur. The lowering of the water table as the number of wells is increased may decrease the yield in the wells and result in an increased cost for water obtained by pumping. In addition, closely spaced wells may interfere with each other resulting in a smaller yield for each of the wells. Although this problem is not serious at the present time in Rhode Island due to the small withdrawal of ground water, the fact remains that as development takes place in particular areas, the potential for these difficulties will increase.

Pollution of ground water is another problem that mist be given careful study and concern. Development in rural and suburban parts of the state where municipal sewage disposal 
systems are non-existent pose a threat to the quality of ground water. As development takes place, the danger of aminating the ground water supply of an area may exist. This is the primary area of concern of this study. 
DESGRIPTION OF THE UPPER PAWCATUCK RIVER BASIN

An appraisal of the ground water reservoirs in Rhode Island was made in 1961 by the U.S. Geological Survey. ${ }^{21}$ Areas demonstrating ground water potential were ranked in order for the following reasons: (1) presence of permeable outwash; (2) weter available for replenishment; (3) undeveloped ground water resources; and (4) no conflict with established surface water uses. 22 It was found that the Upper Pawcatuck River Basin offered the greatest potential for ground water development of any ground water reservoir area in the state, and a recommendation was made for further quantitative studies. These studies were completed by the U.S. Geological Survey in 1966.

Location

The Upper Pawcatuck River Basin is located in the southcentral part of Rhode Island. It includes a major portion of the town of South Kingstown, and also parts of Exeter, West Greenwich, Richmond, and very small portions of North Kingstown, Charlestown, and East Greenwich. Figure 2 shows the Basin's regional location in the state. The Basin is approximately 15 miles long and 7 miles wide with an area of about 70 square miles. To the southeast of the Basin are located the villages of Wakefield and Peacedale and also the town of Narragansett.

${ }^{21}$ S.M. Lang, Appraisal of the Ground Water Reservoir keas in Rhode Island, R.I. Geological Bulletin No. 11 povidence: United States Geological Survey, 1961). 22 Ibid., p. 34 . 
Geohydrologic System

The principal stream in the Basin is the upper part of the Pawcatuck River, which is formed by two main tributaries. These two tributaries are the Usquepaug River, a portion of which is called the Queen River, and the Chipuxet River. The Chipuxet River flows through Wordens Pond and the Usquepaug River flows through Great Swamp before they flow together in the southern part of the Basin to form the Pawcatuck River.

The Upper Pawcatuck River Basin consists of glacially rounded hills and flat valleys. Low, rounded hills are found in the northern half of the basin, while the southern half is basically flat and swampy and forms a plain at altitudes of 90 to 100 feet above sea level. ${ }^{23}$ The boundary of the Basin along the south is a belt of low hills and ridges known as the Charlestown moraine.

The ponds located in the Basin are Wordens, Yawgoo, Barbers, Hundred Acre, Larkin and Tucker. The largest pond is Wordens which is located in the southern part of the Basin and has an area of approximately one and a half square miles. The second largest is Yawgoo which has an area of about one-fourth of a square mile and is located in the central part of the Basin. 24

23William B. Allen, Glenn W. Hahn, and Curtis R. Tuttle, Geohydrological Data for the Upper Pawcatuck River Basin, Rhode Island, R.I. Geological Bulletin No. 13 (Providence: United States Geological Survey, 1963), p. 3.

24william B. Allen, Glenn W. Hahn, and Richard A. Brackley, Availability of Ground Water, Upper Pawcatuck River Basin, Rhode Island, Geological Survey Water Supply Paper 1821 (Washington: United States Geological Survey, 1966), p. 5. 
The geology of the Basin consists of both consolidated and unconsolidated deposits. The consolidated rocks (bedrock) are called crystalline rocks because they are composed of closely fitting mineral crystals. The unconsolidated deposits were lajd down by an ice sheet thousands of years ago and consist of gravel, sand, silt, clay, and till. Till is the principal unconsolidated deposit in the northern part of the Basin, and the wide range of particle sizes makes it a poor water transmitting material. The principal water bearing materials in the Basin are the unconsolidated glacial outwash and Lacustrine deposits and mixed deposits of outwash and till located in the southern part of the Basin. 25

\section{Hydrology}

As mentioned before, ground water cannot be completely isolated without referring to other phases of the hydrologic cycle. All of the water that reaches the Basin comes from precipitation. During the period from 1889 through 1962, the average annual precipitation recorded by the U.S. Weather Bureau at Kingston was 48.39 inches. 26 Part of the precipitation is either stored temporarily in ponds and swamps or leaves the Basin as streamflow. Water also enters the subsurface and moves laterally until it is discharged at springs, into seepage areas in swamps, and along the bottom and sides of streams located in the Basin. Thus, ground water seepage

$$
{ }_{26}^{25} \text { Ibid. }
$$


accounts for most of the flow of streams during periods of no precipitation. The remaining portion of the precipitation returns to the atmosphere through the combined process of evapotranspiration. Wherever water is exposed to the air or is available to plants, evapotranspiration may take place. Air temperature is the primary controlling factor in losses to the atmosphere through the process of evapotranspiration. Evapotranspiration is minimal during the winter when the temperature is low, but increases rapidly as air temperatures rise in the spring and sumer. According to the U.S. Weather Bureau Station at Kingston, the mean annual air temperature is $49^{\circ}$ F. 27 Figure 3 shows the relation between mean annual air temperature and mean ennual water loss in regions such as the Upper Pawcatuck River Basin.

Evapotranspiration may occur from ground water as well as surface water. The amount of ground water lost through evapotranspiration in the entire Upper Pawcatuck River Basin in the 1959 water year was 8.77 inches. 28 The water remaining after evapotranspiration losses have been satisfied is streamflow. This water consists not only of the water that moves over the land after rains and molting of snow, but also ground water that seeps into the streams. Daily discharge records for two stations in the Basin and one station on the Pawcatuck River at Kenyon just below the boundary of the

$$
27 \text { Ibid., p. } 17 \text {. }
$$

${ }^{28}$ Ibid., p. 25 . A water yoar is defined as the 12 month period ending September 30 of the year designated. 
Basin are found in a report published in 1963.29

\section{FIGURE 3}

RETATION OF ANNUAL WATER LOSS TO

AIR TEMPERATURE IN HUMID AREAS

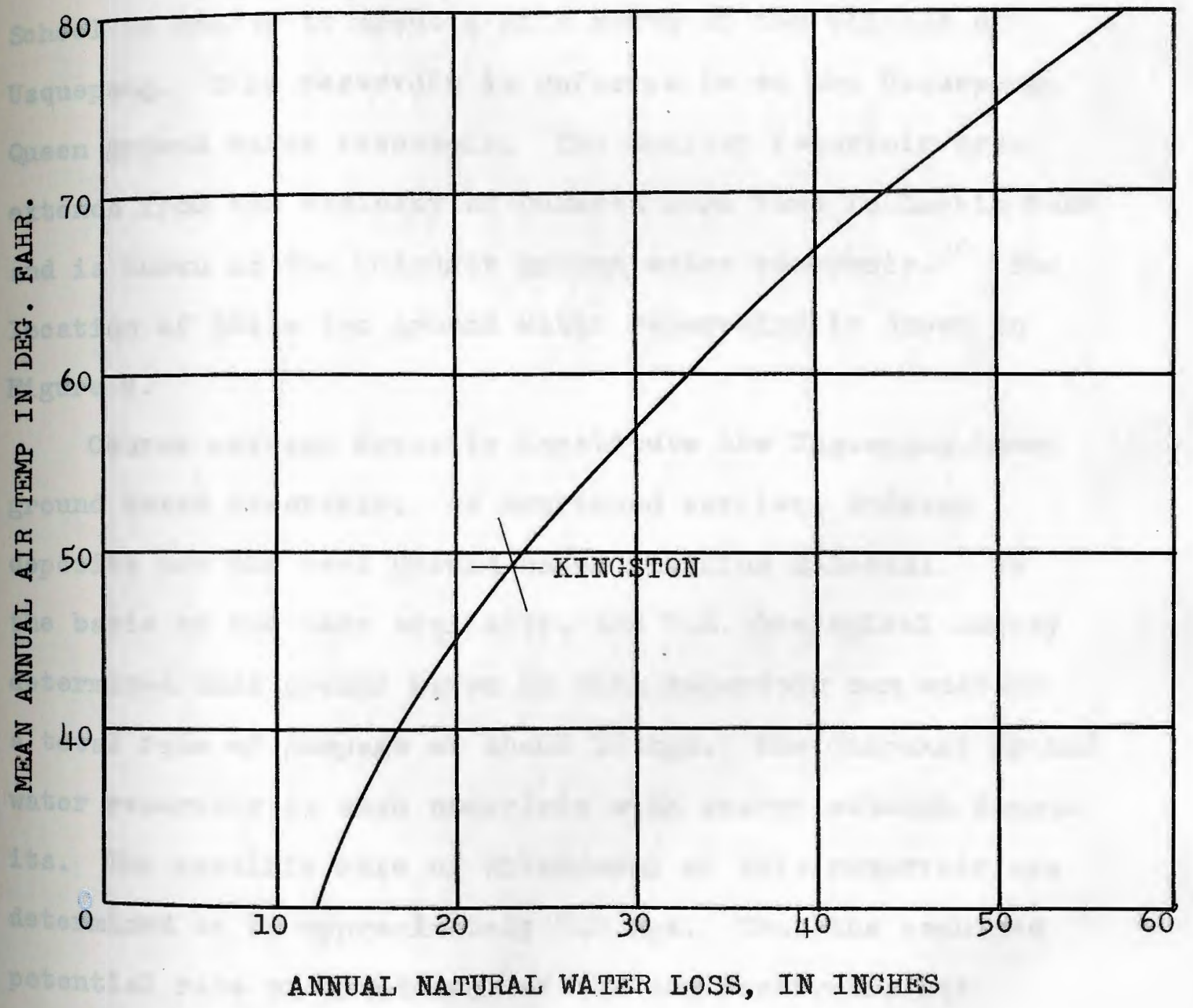

Source: U.S. Geological Survey

${ }^{29}$ Allen, Hahn, and Tuttle, op. eit., p. 31. 


\section{III}

GROUND WATER IN THE UPPER PAWCATUCK RIVER BASIN

Ground Water Potentially Available for Development

Although ground water may be obtained almost anywhere in the Basin, two areas in particular will yield substantial amounts. One extends from approximately the vieinity of Ladd School in Exeter to about a mile south of the village of Usquepaug. This reservoir is referred to as the UsquepaugQueen ground water reservoir. The smaller reservoir area extends from the vicinity of Hundred Acre Pond to Larkin Pond and is known as the chipuxet ground water reservoir. 30 The location of these two ground water reservoirs is shown in Figure 4 .

Coarse outwash deposits constitute the Usquepaug-Queen ground water reservoir. As mentioned earlier, outwash deposits are the best ground water yielding material. On the basis of the data available, the U.S. Geological Survey determined that ground water in this reservoir can sustain a total rate of pumpage of about $17 \mathrm{mgd}$. The Chipuxet ground water reservoir is also underlain with coarse outwash deposits. The possible rate of withdrawal of this reservoir was determined to be approximately $8.6 \mathrm{mgd}$. Thus the combined potential rate of withdrawal of the two reservoirs was reported to be approximately $25.6 \mathrm{mgd} .31$

\footnotetext{
30 Allen, Hahn, and Brackley, op. cit., p. 40. ${ }^{3}$ Ibid., pp. $44-49$.
} 


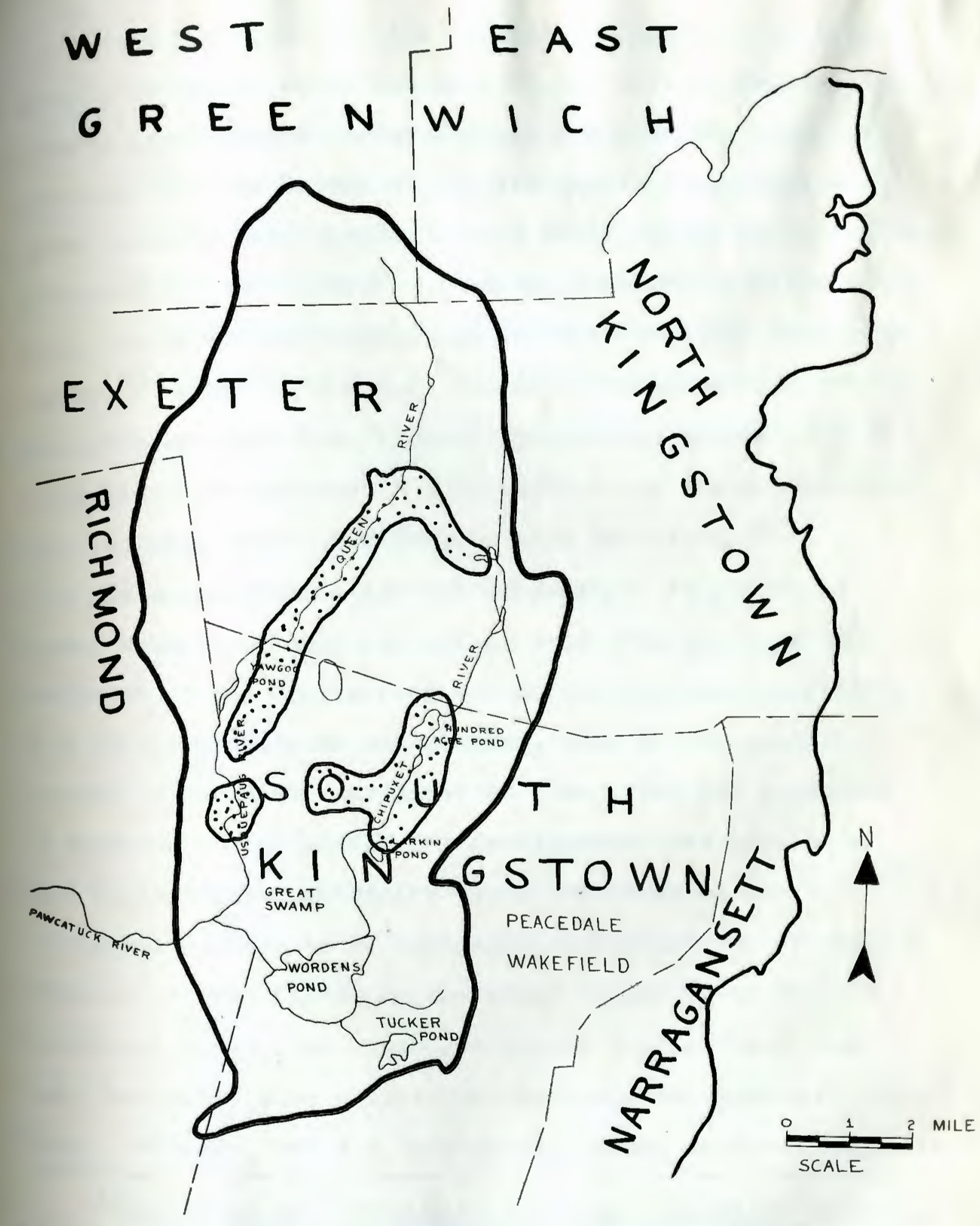

\section{UPPER PAWCATUCK RIVER BASIN, RHODE ISLAND}

FIGURE 4 
Since the time that the initial estimate of the availability of ground water was made by the U.S. Goological Survey, several later reports substantially reduced the figure of $25.6 \mathrm{mgd}$. In the Report of the Governor's Task Force on Water Resource Development, a safe yield figure of $10 \mathrm{mgd}$ was projected for the Basin. 32 A report prepared by Metcalf and Eddy, Inc. estimated that $6 \mathrm{mgd}$ of water could be withdrawn safely. 33 Finally, the R.I. Statewide Comprehensive Transportation and Land Use Planning Prograr has estimated that $8 \mathrm{mgd}$ seems to represent a safe estimate of the ground water supplies that could be withdrawn from the Basin. 34

The major premise for the substantial reduction of ground water available for development from the $25.6 \mathrm{mgd}$ estimated by the U.S. Geological Survey was the possibility that during periods of dry weather, some of the smaller streams in the Basin may cease to flow. The low estimates of ground water available for development that have been made following the extensive study conducted by the U.S. Geological Survey can be seriously challenged for several reasons. First, following the study conducted by the U.S. Geological Survey, no other geological studies have been made that would form a basis for revising the previous findings. Secondly, the U.S. Geological Survey believes that its

32 Report of the Governer's Task Force on Water Resource Planning (Providence: Governorts Task Force, 1967), p. 31. 33 Motcalf and Eddy, Engineers, op. cit., p. E-7.

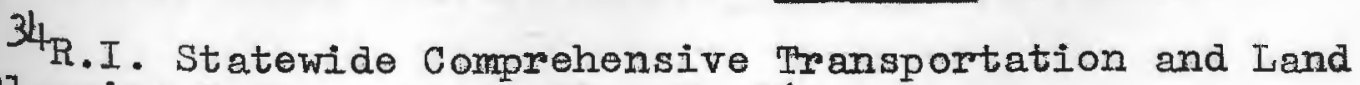
Use Planning Program, op. cit., p. 96. 
estimate of $25.6 \mathrm{mgd}$ is very conservative due to the assumptions that were made in arriving at the $25.6 \mathrm{mgd}$ eigure. 35 Finaliy, the fact that some small streams may be dry for short periods of time does not justify the large reduction of the 25.6 mgd figure arrived at through extensive study by the U.S. Geological Survey. A $70 \%$ reduction in the ground water jield cannot be justified merely on the basis that there exists the possibility that some small streams may be dry during periods of low precipitation. For these reasons, it will be assumed that the estimate of the ground water available for development made by the U.S. Geological Survey is accurate and will be used throughout this study.

Importance of Ground Water to the Area

At the present time, the entire supply of water for all uses in the Upper Pawcatuck River Basin and the immediate towns and villages adjacent to the Basin comes from the ground. In addition to the large number of individual well users found throughout the Basin, there are three water systems that sell water to others located both in the Basin itself and adjacent to it and two institutions that have their own ground water supply wells.

In 1965, the Wakefield Water Company sold water to approximately 6,000 people in South Kingstown and 2,500 people in Narragansett. This water comes from 5 wells 35 Allen, Hahn, and Brackley, op. cit., pp. 61-62. 
which are located in the southern portion of the Upper Paweatuck River Basin, east of Wordens Pond and which have a total capacity of approximately $5 \mathrm{mgd}$. The average daily demand within the system has been about $1.0 \mathrm{mgd}$.

The southern portion of the town of Narragansett also uses water from the Upper Pawcatuck River Basin to serve approximately 2,200 people. This water is purchased from the Wakefield Water Company and is transmitted through mains running along Old Point Judith Road and Ocean Road. This system supplied an average of $0.22 \mathrm{mgd}$ in 1965.

A small system called the Kingston Fire District serves the $\nabla$ illage of Kingston which is located in the eastern portion of the Basin. This system had an average daily demand of approximately $0.05 \mathrm{mgd}$ in 1965 and has a total possible yield of about $0.60 \mathrm{mgd}$. The $0.05 \mathrm{mgd}$ was used to supply water to about 1,300 people.

There are presently two institutional systems in the Upper Paweatuck River Basin that supply water through their own wells. The Ladd School, located in the northern portion of the Basin in the town of Exeter, has two wells with a yield of $0.20 \mathrm{mgd}$. The system also had an average daily demand of about $0.20 \mathrm{mgd}$ and served about 1,000 people in 1965.

The other institutional system in the Upper Pawcatuck River Basin is the University of Rhode Island located in the village of Kingston. Ground water is obtained from three 
wells located east of Thirty Acre Pond. These wells have a yield of approximately $1.90 \mathrm{mgd}$ and have been pumped occasionally at a rate of $1.0 \mathrm{mgd}$ to meet peak demands. The average withdrawal in 1965 was about $0.36 \mathrm{mgd}$; and water was supplied to about 4,600 people. Table 5 is a summary of the water systems and their demands in 1965.

\section{TABLE 5}

WATER SYSTEMS IN THE UPPER PAWCATUCK RIVER BASIN AND DEMANDS (1965)

\begin{tabular}{|c|c|c|c|}
\hline Water System & $\begin{array}{l}\text { People } \\
\text { Served }\end{array}$ & $\underbrace{\text { Yield Gapacity }}_{\text {(mgd) }}$ & $\begin{array}{l}\text { Average Daily } \\
\text { Demand } \\
\text { in } 1965 \text { (mgd) }\end{array}$ \\
\hline $\begin{array}{l}\text { Wakefield Water. Co. } \\
\text { Narragansett }\end{array}$ & $\begin{array}{l}8,500 \\
2,200\end{array}$ & $\begin{array}{l}\quad 5.0 \\
\text { Water Purchased } \\
\text { from Wakefield } \\
\text { Water Co. }\end{array}$ & $\begin{array}{l}1.0 \\
0.22\end{array}$ \\
\hline Kingston Fire District & 1,300 & 0.60 & 0.05 \\
\hline Ladd School & 1,000 & 0.20 & 0.20 \\
\hline \multirow[t]{2}{*}{ U.R.I. } & 4,600 & 1.9 & 0.36 \\
\hline & 17,600 & & 1.83 \\
\hline
\end{tabular}

Source: Preliminary Plan for Public Water Supply and Distribution. Ground Water Reservoirs of the Kington Quadrangle, Rhode Island.

As the communities located within and adjacent to the Upper Pawcatuck River Basin develop and grow, the demand for utilities will undoubtedly increase. The fact that a large ground water supply underlies the area means that any plans for future development must give careful consideration to this valuable resource. Past withdrawal by the Wakefield Water Company indicates that the demand for water in the 
area is increasing. Table 6 shows the pumpage rates for various jears from 1945 to 1965, while Figure 5 is a graph showing how the average daily pumpage of ground water by the Wakefield Water Company has been increasing since 1951. Since 1951, the gearly increase in the average daily punpage of ground water has averaged approximately .024 mgd.

\section{TABLE 6}

PUMPAGE BY THE WAKEFIELD WATER COMPANY (mgd)

\begin{tabular}{l|c|c}
\hline Year & Total Annual & Average Daily \\
\hline 1945 & 202.7 & 0.556 \\
1946 & 177.3 & 0.480 \\
1947 & 179.5 & 0.490 \\
1948 & 206.7 & 0.567 \\
1949 & 226.0 & 0.620 \\
1950 & 214.3 & 0.587 \\
1951 & 214.4 & 0.587 \\
1952 & 235.1 & 0.642 \\
1953 & 254.3 & 0.697 \\
1954 & 277.4 & 0.766 \\
1955 & 290.9 & 0.797 \\
1958 & 301.6 & 0.830 \\
1959 & 315.8 & 0.870 \\
1965 & n.a. & 1.000 \\
\hline
\end{tabular}

Source: Preliminary Plan for Public Water Supply and Distribution. Ground Water Resour ces of the Kingston Quadrangle, R.I. Ground Water Levels in Rhode Island 1958, 1959.

The town of South Kingstown is the most highly developed tow in the Basin and also possesses the most promising growth factors. Proximity to the University of Rhode Island and the Atlantic Ocean, along with the various commercial facilities located in the town, indicates that future growth is inevitable. Most of the future growth will take place 


\section{FIGURE 5}

RELATIONSHIP BETWEEN YEARS AND AVERAGE DAILY PUMPAGE OF GROUND WATER BY THE WAKEFIELD WATER COMPANY

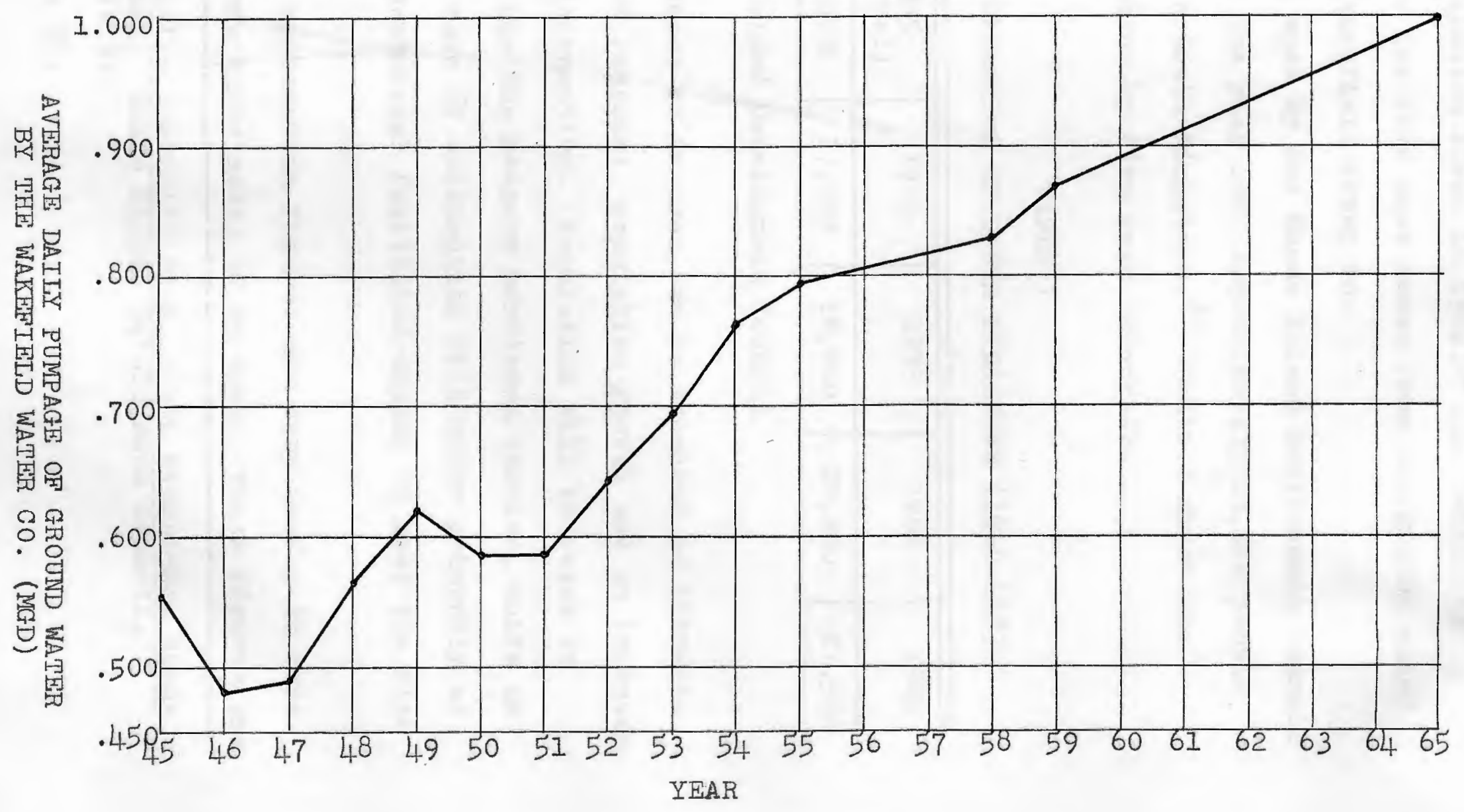


around the Wakefield Peacedale area where approximately $4 \%$ of the total population lived in 1960.36 As mentioned previously, water for this area comes from the ground water supplies of the Wakefield Water Co.

Projections made by the Rhode Island Development Council indicate that by the year 1985 approximately 21,550 people will be living in South Kingstown. 37 Table 7 shows the projected population by five year intervals.

\section{TABLE 7}

PROJECTED POPULAPION OF SOUTH KINGSTOWN (1960-1985)

\begin{tabular}{c|c|c|c|c|c}
\hline $\begin{array}{c}1960 \\
\text { (Actual) }\end{array}$ & $\begin{array}{c}1965 \\
\text { (Actual) }\end{array}$ & 1970 & 1975 & 1980 & 1985 \\
\hline 11,942 & 15,500 & 17,300 & 18,800 & 20,200 & 21,550 \\
\hline
\end{tabular}

Source: Rhode Island Development Council

The water needs of an area can be expected to increase primarily for two reasons: population growth and an increase in the rate of consumption. Population will increase in South Kingstown for the reasons mentioned earlier, while an increase in the rate of consumption will occur primarily as industrial and commercial facilities expand to meet the rise in population.

Per capita consumption figures are very useful in forecasting the future water needs of an area. These figures are

${ }^{36}$ Comprehensive Community PI an, South Kingstown, Rhode Islane (Providence: Rhode Island Develepment Council, January $(965), p .54$.

$$
37 \text { Ibid., p. } 55 \text {. }
$$


obtained by simply dividing the water consumed by the population served. The increasing amount of water demanded by dishwashers, washing machines, air conditioners, and other water consuming appliances, together with the increased use of water for such activities as lawn sprinkling, have resulted in an increasing per capita consumption over the years. Table 8 shows both the projected population for South Kingstown and the corresponding estimates of the per capita consumption rates.

\section{TABLE 8}

PROJECTED POPULATION AND CORRESPONDING PER CAPITA CONSUMPTION RATES BASED ON A 1.5 GALLONS PER CAPITA PER YEAR INCREASE FOR SOUTH KINGSTOWN

\begin{tabular}{l|r|r|r|r|r}
\hline \hline Year & 1965 & 1970 & 1975 & 1980 & 1985 \\
\hline Population & 15,500 & 17,300 & 18,800 & 20,200 & 21,550 \\
\hline $\begin{array}{l}\text { Per Capita } \\
\text { Consumption } \\
\text { (gals. per capita } \\
\text { per day) }\end{array}$ & 106 & 114 & 121 & 129 & 136 \\
\hline
\end{tabular}

Source: Rhode Island Development Council. R.I. Statewide Comprehensive Transportation and Land Use PIanning Program.

In order to determine the future demands for water, the estimate of the future population to be served has to be multiplied by the per capita consumption rate. On this basis, the demand for water in South Kingstown in the year 1980 will be approximately $2.6 \mathrm{mgd}$, which represents a $52 \%$ increase over the $1.65 \mathrm{mgd}$ demand in 1965 . 
The town of Narragansett may also be expected to make increased demands for water in the future. The construction and improvernent of highways and the construction of the bridge to Newport have placed Narragansett within easy commuting distance of the Greater Providence Metropolitan Area. Planning for Narragansett must consider its resort character; however, the summer resort nature of the town is not as strong as it has been in the past. Redevelopment planning for the Narragansett Pier area can also be expected to increase the growth potential of the town.

In 1965, the Wakefield Water Company wells supplied water to about 4,700 of the 5,043 permanent residents of the town. At that time, there was an average daily demand of $0.30 \mathrm{mgd}$ and a per capita consumption rate of 64 gallons per capita per day (gpcpd). 38 Estimates of water requirements for 1980 indicate that Narragansett may have an average daily demand of $0.90 \mathrm{mgd}$ and a per capita consumption rate of $135 \mathrm{gpcpd}$, in serving 6,600 people. 39 Thus, the demand for water in 1980 may be $0.60 \mathrm{mgd}$ greater than what it was in 1965. This 0.60 mgd represents a $100 \%$ increase over the average daily demand in 1965.

It is very difficult to estimate the future water demands of the University of Rhode Island because any forecasts for

38 R.I. Statewide Comprehensive. Transportation and Land Use Planning Program, op. cit., p. 45. 39 Tbid., p. 55 . 
the University population are very uncertain. The University itself has only made forecasts to the year 1974, and these only cover the student enrollment. The University's projection of student enrollment to 1974 is $11,300.40$ Projections of water requirements for the University have not been made. However, as the University population grows due to the increasing emphasis on higher education, the demand for water can also be expected to increase.

Predicting future water demands for other towns located in the Upper Pawcatuck River Basin cannot be done with any degree of accuracy because of their mural nature. For example, as of 1965, the town of Exeter had a density of only 52 inhabitants per square mile of land area. 41 other towns located in the northern portion of the Basin also display this rural character. With the exception of Ladd School in Exeter, there are no public or institutional water supply systems located in these towns, and therefore the people depend entirely on private wells for their water. If development should take place in the future in these areas, then the demands for water would obviously increase proportionately.

In summary, ground water is of major importance in considering the growth of towns located in and adjacent to the Upper Pawcatuck River Basin. The towns of South Kingstown

40 Telephone communication with Mr. Huet, University of Rhode Island, Department of Institution Research, Aug. 1, 1969. 41

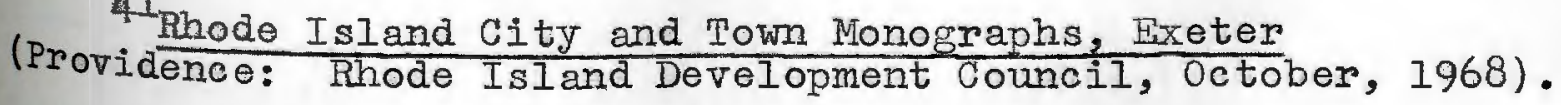


and Harragansett have promising growth factors, while the University of Rhode Island can also be expected to grow. With the expected increase in population, and the trend toward increasing rates of consumption, water demands will necessarily increase. Since the already developed surface water reservoirs are located in the northern part of the state and there are no potential surface water reservoir sites in the vicinity of the Upper Pawcatuck River Basin, the possibility of supplying the people of the basin with water from surface reservoirs must be discounted due to the enormous cost of transmitting water for great distances. Since both the towns and villages in the Basin itself and those adjacent to it such as Wakefield and Peacedale are exclusively dependent on ground water for their water supply, the importance of ground water to these areas cannot be overemphasized. 
POLLUTION OF GROUND WATER

Causes of Pollution of Ground Water

As mentioned before, all water problems are basically ones of quantity or quality. The prime concern in the arid west is water quantity, while water quality is the major problem in the east. Like surface water, ground water can be adversely affected by man's activities. Material such as sewage and industrial wastes may enter a ground water supply and pollute it. If pollution occurs to the degree that the water supply is hazardous to public health, then the supply is considered contaminated. Table 9 is an outline of the various causes of deterioration of ground water quality.

\section{TABLE 9}

CAUSES OF DETERIORATION OF GROUND WATER QUALITY42

I. Contamination and Pollution

1. Domestic and Municipal Sewage

2. Industrial Wastes

a. Organic wastes

1. food processing

2. lumber processing

b. Mineral wastes

1. metal processing industries

2. mining and ore extraction industries

3. oil industries

4. chemical industries

5. miscellaneous

42 David Keith Todd, Ground Water Hydrology (New York: John Wiley and Sons, Inc., 1959), pp. 195-196. 
TABLE 7--Continued

c. Cooling water

3. Solid and Semisolid Refuse

II. Degradation--Effects of Development, Use, and Reuse of Water

1. Irrigation return water

a. surface drainage

b. percolation

2. Interchange between acquifers due to improperly constructed, defective, or abandoned wells.

3. Interchange between acquifers due to differentials in pressure levels resulting from excessive withdrawal.

4. Overdraft conditions

a. sea water intrusion

b. salt balance

c. upwara or lateral diffusion of connate brines and/or juvenile water due to overpumping

5. Contamination from the surface due to improperly constructed wells

6. Natural causes

Inflow and/or percolation of juvenile water from highly mineralized springs and streams

7. Other causes

a. accelerated erosion

b. mineralization resulting from plant transportation and/or evaporation

Pollution of Ground Water in the U.S.

Pollution of ground water is not a problem that is restricted only to certain portions of the United States. In 1960, the American Water Works Association made a survey of ground water contamination in the United States from 
information collected from replies to a questionnaire.

The survey revealed that:

of the 48 states that returned the questionnaire, 9 indicated no reported or observed contamination problems; 26 states indicated contamination by sewage; 22 reported oil and gas production waste or petroleum products contamination; 15 indicated other industrial waste or chemical contaminants; and 13 reported problems which developed from contaminants of another nature. 43

The fact that only 9 out of 48 states had no contamination problems indicates that a widespread ground water pollution problem does exist.

\section{Water Quality Analysis}

In order to realize the quality of a ground water supply, it must be determined what chemical, physical, and bacterial constituents are present in the supply. Standards must then be applied to determine whether the water is acceptable for a particular use. For the purpose of this study, it will be assumed that the water is to be used primarily for human consumption. It mist be emphasized that various uses may have different water quality standards. Thus, water that may be unacceptable for human consumption may be adequate for another use. 44 Most of the states in the country have adopted the standards set forth by the U.S. Public Health Service for their drinking water supplies. In addition, the Public Health

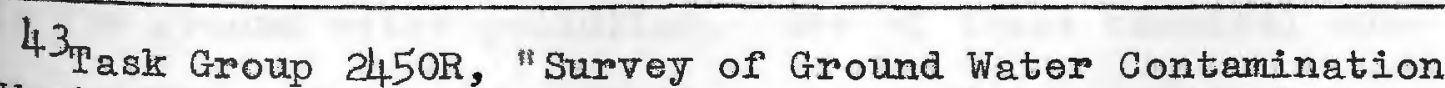
and Waste Disposal Practices", Journal of the American Water Works Association, 52 (November, 1960), 1212 .

${ }^{44}$ See Water Quality Griteria, Publication No. 3-A (Sacramento: California State Water Quality Control Board, 1963). 
Service has determined standard methods of examining water for chemical, physical, and bacterial constituents. 45 Chemical Constituents

obviously, it is not practical to test water for every undesirable chemical constituent which may enter a particular supply of water. Therefore, the Public Health Service has developed standards for the chemical substances which represent a hazard to the health of man. Table 10 lists the chemical substances which should not be found in a water supply in excess of the given concentrations where other more suitable supplies can be obtained. In other words, a water supply containing any of the listed chemical substances in the concentrations given should be used only when no alternative means of water supply is available due to the potential health hazard to individuals consuming the water. If a water supply contains any of the chemical substances in the concentrations given in Table 11 , it must be rejected entirely as a source of drinking water.

Pollution of Ground Water by Synthetic Detergents

Although the preceding standards have been developed for both surface and ground supplies, particular attention should be given to the chemical substances that are primarily responsible for ground water pollution. One of these chemical substances is the synthetic organic chemical known as Alkyl

45 U.S. Public Health Service, Drinking Water Standards, Public Health Service Publication 956 (Washington: U.S. Government Printing office, 1962). 
LIMITS OF CONCENTRATIONS OF CHEMICAL SUBSTANCES WHERE OTHER MORE SUITABLE WATER SUPPLIES ARE OR CAN BE MADE AVAILABLE46

Substance

Concentration in milligrams per liter (mg/l)

Alky Benzene Sulfonate (ABS)

Arsenic (AS)

Chloride (CI)

Copper (Cu)

Carbon Chloroform Extract ( $\mathrm{CCE}$ )

Cyanide (CN)

Fluoride $(F)$

Iron (Fe)

Manganese (Mn)

Nitrate $\left(\mathrm{NO}_{3}\right)$

Phenols

Sulfate $\left(\mathrm{SO}_{4}\right)$

Total Dissolved Solids

Zine $(\mathrm{Zn})$

$$
\begin{gathered}
0.5 \\
0.01 \\
250 . \\
1.0 \\
0.2 \\
0.01 \\
1.2^{2} \\
0.3 \\
0.05 \\
45.0 \\
0.001 \\
250 . \\
500 . \\
5 .
\end{gathered}
$$

athis is the limit for Rhode Island. The limit for fluorides is based on the annual average of maximum daily air temperature.

\section{TABLE 11}

LIMITS OF CONCENTRATIONS OF CHEMICAL SUBSTANCES THAT CONSTITUTE GROUND FOR REJECTION OF A WATER SUPPLY47

\section{Substance}

\begin{tabular}{l} 
Arsenic (As) \\
Barium (Ba) \\
Cadmium (Cd) \\
Chromium (Hexavalent) (Cr 6) \\
Cyanide (CA) \\
Fluoride (F) \\
Lead (Pb) \\
Selenium ( Se) \\
Silver (Ag) \\
\hline
\end{tabular}

Concentration in $\mathrm{mg} / \mathrm{l}$

$$
\begin{aligned}
& 36 \text { Ibid., p. } 7 . \\
& 47_{\text {Ibid., p. } 8} .
\end{aligned}
$$
0.05
1.0
0.01
0.05
0.2
2.4
0.05
0.01
0.05 
Benzene Sulfonate, or more commonly referred to as ABS. $A B S$ is one of the major constituents of syndets, which are the poprlar synthetic detergents which are replacing soap as a cleansing agent. The reason for the popularity of syndets is that, unlike soap, syndets do not require the interaction with calcium and magnesium to form a lather before the eleansing action starts. Since syndets are unaffected by hardness salts in water, they are able to cleanse much sooner than soap.

Although syndets are very useful as cleansing agents, the $A B S$ found in them can affect the quality of ground water where septic tanks are used for disposal. The fact that ABS originates only in sewage discharges can definitely establish contamination in a well by a homeowner's ow sewage or that of his neighbors'.

The presence of ABS in water may cause unpleasant taste and frothing. In a study conducted in Babylon, New York on Long Island, $10 \%$ of those people using ground water with less than $1 \mathrm{mg} / 1$ of syndets complained of an off-taste, while $100 \%$ of those using water having $1.5 \mathrm{mg} / \mathrm{I}$ of syndets complained of an off-taste. Frothing al so occurred at concentrations of $I \mathrm{mg} / \mathrm{I}$ and above. 48 As a result of the syndet problem in this area, the Federal Housing Administration would not approve mortgages when a well and a sewage disposal system

48

J.M. FIJnn, Aldo Andreoli, and A.A. Guerrera, "Study of Synthetic Detergents in Ground Water", Journal of the American Water Works Association, 50 (December, 1958), 1561. 
were to be located on the same lot, unless certain strict conditions were met. 49

Although it has been determined that man and animal can tolerate relatively high levels of $A B S$ in drinking water, the fact that $A B S$ may be present in the water indicates that other wastes originating from sewage are present. 50 In adition, the fact that synthetic detergents are only party removed by a septic tank and absorption field, combined with the fact that they are very stable chemicals make them a serious problem affecting ground water quality. The phosphates found in synthetic detergents may also contribute to the pollution of ground water by enhancing the medium for bacteria, thus increasing their numbers and survival time.

\section{Pollution by Chlorides}

Chlorides are usually found in all natural waters due to contact with natural minerals. However, chlorides may also originate from: (a) sea water contamination of underground supplies, (b) salts spread on fields for agricultural purposes, (c) human or animal sewage, or (d) industrial effluents. 51 The chlorides found naturally in ground water are usually not harmful to human beings, although chlorides may be harmful to

49. I.G. Campenni, "Synthetic Detergents in Ground Waters-Part I", Water and Sewage Works, 108 (196I), 188.

50 Graham Walton, "ABS Contamination of Water Resources", Journal of the American Water Works Association, 52 (November, ${ }^{5} I_{C a l i f o r n i a}$ State Water Pollution Control Board, op. cit., p. 160 . 
some people having heart or kidney diseases. The real significance of chlorides in a ground water supply is not so much that the water may have an undesirable taste, but the fact that any sudden inerease in the chloride content of a supply may be indicative of pollution from sewage. 52

Pollution by Nitrogen Matter

Compounds of nitrogen are chemical constituents which may cause ground water pollution. Excessive amounts of nitrogen in the form of ammonia or nitrites indicate recent pollution, while the presence of nitrates in ground water indicates pollution that has existed for some time.

The most dangerous of the nitrogen compounds are the nitrates. Nitrates usually occur in ground waters due to the excessive application of fertilizer or the effluent that enters the soil from septic tanks. Ground water polluted by nitrates has been known to cause serious blood changes in infants who consumed it. In some cases, ground water containing nitrates has proved fatal to babies drinking it. 53

Nitrites are formed in water by the action of bacteria upon ammonia and organic nitrogen. Whenever nitrites are found present in a ground water supply in conjunction with ammonia and nitrates, this may signify pollution by sewage.

\section{Ibid.}

53 H.M. Bosch, A.B. Rosenfield, H.R. Shipman, and R.I. Woodward, "Methemoglobinemia and Minnesota Well Supplies", Journal of the American Water Works Association, 42 (July, 1950). 
physical Characteristics of Ground Water

Ground water may also be undesirable for human consumption due to its physical characteristics. Turbidity, color, odor, and taste may be reason enough for rejecting a ground water supply. Turbidity of water is a measure of the extent to which the intensity of light passing through is reduced by suspended matter such as clay, silt, and microscopic organisms. Mineral or organic matter in the water may be the cause of undesirable color, while tastes and odors may be due to gases, mineral matter, or bacteria entering the ground water supply.

The following limits of turbidity, color, and odor have been defined by the U.S. Public Health Service. These are the levels at which these characteristics become objectionable to most people.

\section{TABLE 12}

DRINKING WATER PHYSICAL CHARACTERISTIC STANDARDS 54

Turbidity

Color
5 parts per million

15 units (standard cobalt scale)

Threshold Odor Number 3

Bacterial Pollution

Bacterial pollution of ground water is due primarily to sewage being introduced into the ground and eventually reaching

$54_{U} . S$. Public Health Service, op. cit., p. 6. 
the ground water. Since there are a vast number of bacteria which may be harmful to the health of man, testing for each type of bacteria would be impractical. Instead, water is examined for fecal contamination by testing for the coliform group of bacteria, since this group of bacteria are found in the intestinal tract of animals and people. 55

Enteric viruses such as infectious hepatitis may also enter a ground water supply as a result of disposal of human waste into the ground by means of septic tanks. Although domestic sewage usually contains about 10,000 times as many coliform bacteria as virus, the chance of epidemic by virus cannot be overlooked. 56

55 For a more detailed description of the standard test for coliform bacteria see Drinking Water Standards, 1962 , U.S. Public Health Service. ${ }^{56} \mathrm{~S}$. Kelly, J. Winsser, and W. Winizelstein, Jr., "Poliomyclitis and Other Enteric Viruses in Sewage", American Journal of Public Health, 47 (January, 1957), 73. 


\section{MOVEMENT OF POLLUTANTS}

An understanding of the bacterial, organic and mineral matter that may affect the quality of ground water must be accompanied by a knowledge of how the pollutants reach the ground water table and how the pollutants travel once they have entered the ground water supply. Pollutants introduced into the ground go through two phases of movement: the finst is through the zone of aeration, and the second is through what is known as the zone of saturation. Figure 6 shows these two zones.

\section{FIGURE 6}

PHASES OF MOVEMENT FOR POLLUTANTS

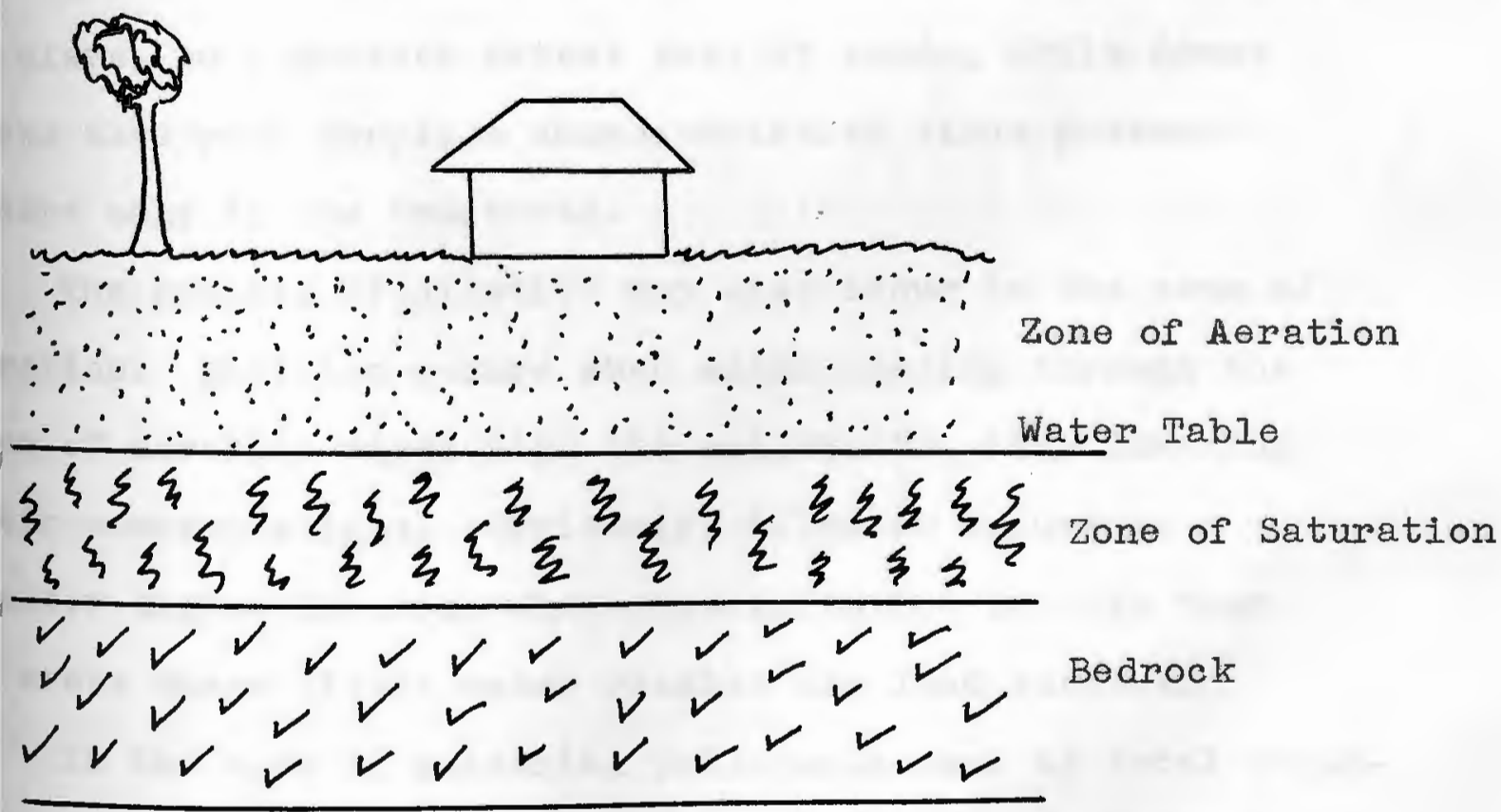


Movement in the Zone of Aeration

When pollutants are introduced into the zone of aeration, movement occurs almost entirely in the vertical direction until the water table is reached. This movement through the soil may have some important effects on the pollutants. However, the tremendous variety of pollutants that may be intreduced into the ground differ in their behavior in the zone of aeration.

Some pollutants may never reach the water table because they are retained by the soil in the zone of aeration. During the vertical movement towards the water table, the pollutants may react chemically with the soil. This is known as the process of sorption. The degree to which sorption may occur depends on the pollutants and the materials through which they pass. Most pollutants will be retained by clays, to a greater extent than by sands, while dense rocks have poor sorption characteristics since movement occurs only in the fractures.

The process of dilution may also occur in the zone of aeration. Dilution occurs when water passing through the zone of aeration mixes with the pollutants, thus lowering their concentrations. Obviously, dilution occurs to a greater degree in areas where precipitation is high than in areas where little water reaches the land surface.

In the case of bacterial pollutants such as fecal organisms, the accumulation of sludge may cause the dangerous organisms to either never reach the water table or to be in 
a harmless state once they do. When bacterial pollutants move through the zone of aeration, the pore spaces of the soil may become clogged causing the formation of a sludge layer. The sludge layer prevents the advance of the pollutants, and as the depth of the layer increases, the bacterial pollutants will eventually die since the close proximity of the organisms will prevent them from getting the oxygen necessary for their survival. The finer the grain of the soil is, the more effective this "choking" process will be. Even though bacterial pollutants may never reach the ground water due to the filtering action that may take place in the zone of aeration, the danger of organic pollutants originating in sewage or other sources may still be a hazard. Organic matter is not removed as rapidly as the bacteria, since it requires oxygen for its mineralization. More significantly, mineralization occurs more effectively if the oxygen is atmospheric oxygen, which is found only near the land surface. In addition, organisms that are capable of oxidizing organic matter are also found near the land surface. Therefore, organic matter that is introduced at a substantial depth below the land surface may not be oxidized completely and may proceed through the zone of aeration to enter the ground water, thus polluting it.

\section{Movement in the Zone of Saturation}

Once pollutants have reached the zone of saturation, their movement becomes altered, and movement in the lateral 
direction predominates. Furthermore, the pollutants move in the same direction as the ground water, which is towards areas of discharge such as stream valleys. In addition, the pumping of wells may divert the pollutants from their natural movement and cause the pollutants to enter the wells. once polluted water has entered a well, it will flow radially outward from the well into the aquifer. This radial flow is controlled by the natural hydraulic gradient in the aquifer or by the gradients created by wells in the vicinity of the polluted well. Therefore, all wells that are in the proximity of a well containing polluted water are themselves in danger of pollution, since their pumping may cause water from the polluted well to be drawn into the unpolluted wells. The mechanisms that affect the pollutants in the zone of aeration also act in the zone of saturation. These mechanisms include dilution, filtration, decay, and sorption. However, it is extremely difficult to determine the exact effect of these mechanisms due to the tremendous variety of pollutants and also to the many hydrologic factors acting in the saturated zone. These factors include the geology, the hydraulic gradient, the permeability of the material, and the temperature of the water. Although it is beyond the scope of this study to consider all of the above factors, examples of the distances that some pollutants have been known to travel can be cited. Table 13 is the result of experiments conducted throughout the country at various times and was compiled by the California State Water Pollution Control Board. 


\section{TABLE 13}

EXAMPLES OF DISTANCE AND TIME OF TRAVEL OF VARIOUS TYPES OF POLLUTANTS57

\begin{tabular}{|c|c|c|c|}
\hline Nature of Pollution & Pollutant & $\begin{array}{l}\text { Observed } \\
\text { distance } \\
\text { of travel } \\
\text { (feet) }\end{array}$ & $\begin{array}{l}\text { Time of } \\
\text { travel }\end{array}$ \\
\hline
\end{tabular}

sewage polluted trenches intersecting ground water coliform bacteria 6527 weeks river water in abandoned wells intestinal pathogens tracer salts

$800 \quad 17$ hours $800 \quad 17$ hours

coliform organisms

introduced into soil colfform bacteria 164. 37 days

Introduced bacteria serratia marcescens

699 days

chlorinated sewage dye 30024 hours

Industrial wastes

puric acid chromate $15,840 \quad 4-6$ years I,000 3 years

salt chlorides

200 24 hours

weed killer wastes

chemical

105,600

6 months

57 Report on the Investigation of Travel of Pollution (Sacramento: California State Water Pollution Control Bo ard, 1954), p. 22 . 
POLLUTION OF GROUND WATER IN THE

UPPER PAWCATUCK RIVER BASIN

In order to determine the degree of pollution that presently exists in the ground water of the Upper Pawcatuck River Basin, analysis must be made of the chemical, physical, and bacterial constituents that are present. In 1959, the U.S. Geological Survey in cooperation with the R.I. Division of Sanitary Engineering conducted a chemical analysis of samples of ground water from 41 wells located in the Basin: these included 3 wells penetrating bedrock, 30 wells penetrating glacial outwash, and 8 wells penetrating glacial till. 58 Iron and manganese were found to be problems in the Chipuxet ground water reservoir, although these minerals were restricted to a lower a quifer. In addition, a well used by the University of Rhode Island was found to contain iron and manganese in excess of the limits recommended by the U.S. Public Health Service. Finally, water from a well in the village of Kingston showed an excessive amount of nitrates. The source of the nitrates was never determined.

The Phode Island Department of Health Water Analysis

The Rhode Island Department of Health conducts a continuing program of water analysis of wells for any resident of the state who may request this service. The substances

58

Allen, Hahn, and Tuttle, op. cit., pp. 51-54. 
analyzed may not necessarily be harmful in themselves, but may be indicative of pollution by sewage. The judgements that the Department makes are based on the quantity and type of pollutant present and are made through the application of the standards developed by the U.S. Public Health Service. The results of the water analysis together with recommendations are submitted to the party requesting the examination. The water analysis itself consists of a determination of the physical characteristics, the chemical constituents, and the bacterial matter present in the water supply. The physical analysis consists of an investigation of color, turbidity, sediment, and odor, while the ehemical examination determines the presence of nitrogenous organic matter, chlorides, and synthetic detergents. The bacteriological examination determines if the coliform group of bacteria are present in the ground water supply.

It should be emphasized that the Rhode Island Department of Health does not carry out a systematic compulsory program of private well analysis. The well analysis data used in this study are the result of analyses of ground water requested by property owners Iocated in the Upper Pawcatuck River Basin. Since the program is entirely voluntary, an assumption may be made that unless an owner suspects there is something wrong with his water supply, he most likely will not have a water analysis performed. Therefore, there may exist in the Basin polluted wells for which a water quality examination has never been performed. 
Analysis of Private Well Data

During the sumer of 1969, the results of the wells tested in the towns of South Kingstown and Exeter during the year 1968 and up to september 1969 were obtained from the Rhode Island Department of Health. It should be made clear that the results presented in this study are for a very specific period of testing. Other wells tested during years not covered by this study may be polluted, but this fact would not be evident from analyses of the data gathered for this study. Data were obtained for 157 wells tested during the forementioned period. For each well tested, the Rhode Island Department of Health forwarded to the property owner a summary of the results of the test. These summaries may be found in the Appendix of this report. Because the results of the tests for the individual wells overlap, they have been categorized by the author into five areas:

1. Overall safety of the water supply for human consumption.

2. Bacteriological examination conclusions.

3. Chemical examination conclusions.

4. Physical characteristics.

5. Imperfections in construction and/or placement of well and/or disposal system.

The following is a summary of the results of the individual tests of the 157 wells analyzed.

\section{Overall Safety of the Water Supply} for fiuman Consumption

76 samples represented water safe at the time of collection of the sample 
II samples represented water safe at the time of collection, but traces of harmless contamination were present.

23 samples represented water safe at the time of collection, but there were traces of harmless contamination that were too pronounced to allow assurance that the water will remain safe.

I4 samples indicated such conditions that it was doubtIul if the supply could be made satisfactory. A recommendation was made that another supply should be sought.

33 samples had no roport in this category.

\section{Bacteriological Bxamination Conelusions}

32 samples had bacterial results that indicated such a high degree of pollution that the water had to be reported unsafe.

5 samples had satisfactory bacterial results.

120 samples had no report in this category.

\section{Chemical Examination Conclusions}

I4 samples had chemical results of sanitary significance that were satisfactory.

Il samples had chemical results of sanitary significance that were indicative of pollution to a degree that made it necessary to consider the water unsafe.

9 samples had chemical results of sanitary significance which showed the presence of synthetic detergent (provides additional evidence of sewage pollution).

7 samples indicated a presence of nitrates so high that water should not be consumed by infants due to the possibility of development of methemoglobinemia (blue baby).

6 samples had chemical results of sanitary significance that were suggestive of some pollution.

110 samples had no report in this category.

\section{Physical Characteristics}

87 samples had physical characteristics which were good. 
34 samples had physical characteristics which were fair. 21 samples had physical characteristics which were poor. 15 samples had no report in this category.

Imperfections in Construction and/or
Placement of Well and/or Disposal System

88 samples showed that surface material was entering the well through the top of the well casing or other imperfection in the well.

76 samples showed that the sewage seepage system was located less than 100 feet from the well and/or on higher ground than the well.

31 samples showed that a privy was located less than 65 feet from the well and/or on higher ground than the ตอ11.

11 samples showed that the location of the well in the basement of the building was unsafe.

9 samples exhibited the need for cleaning and repairing of the well in addition to chlorination.

Overall Safety of the Water Supply for Human Consumption

of the total 157 wells tested only 76 were reported as being free from all contamination and safe for human consumption. Thus, only $48 \%$ of the private wells tested had ground water that was physically, chemically, and bacteriologically safe. Thirty-four other wells supplied water that was safe for human consumption, but traces of harmless contamination were present. However, the fact that the contamination was harmless at the time of analysis does not insure that the water will remain safe in the future. The Health Department recomended that 14 other wells should be discontinued as a source of water, and that another supply should be sought. 
The reming 33 wells, therefore, supplied water that was not free of contamination, but yet could be used for human consumption. The fact that only less than half of the wells tested were found to be supplying water with no trace whatsoever of harmful constituents indicates that pollution of ground water is a serious concern in the Upper Paweatuck River Basin.

\section{Bacteriological Fxamination Conclusions}

The bacteriological characteristics reported for the 157 wells show that only 5 samples had satisfactory results, while 32 other wells had bacterial results that indicated the water should not be used for human consumption. Thus, 120 wells showed evidence of bacteria; however, at the time of testing, the water could still be assumed safe for human consumption. The fact that some harmful bacteria were detected may be an indication of problems at a later time.

Chemical Examination Conclusions

Approximately $9 \%$ or It of the 157 wells tested had completely satisfactory chemical results, while water from 11 other wells exhibited chemical qualities that were indicative of pollution to the degree that the ground water should not be used as a source of water supply. Only 9 wells supplied ground water that had chemical results which showed the presence of excessive amounts of synthetic detergent, while 7 samples indicated a presence of nitrates so high that the Health Department recommended that the water should 
not be consumed by infants due to the possibility of development of methemoglobinemia (blue baby). The remaining 116 wells, therefore, supplied water that exhibited traces of chemical pollution, but the ground water was not considered dangerous to health, and could continue to be used provided the chemical pollution does not increase. In summary, the potential for chemical pollution problems in the majority of weIls exists.

\section{Physical Characteristics}

As explained earlier, the physical characteristics that were considered in the water quality examination were color, turbidity, sediment, and odor. The State Health Department reported that: 87 wells had physical characteristics which were good; 34 samples had physical characteristics which were fair; and 21 samples had physical characteristics which were poor. The 15 remaining wells of the 157 tested were given no report on their physical characteristics because previous analyses had shown that these characteristies were acceptable. Therefore, approximately $85 \%$ or 121 of the 142 wells for which results were given had physical characteristics which were either good or fair.

Imperfections in Construction and/or Placement of Well and/or Disposal System

The bacteriological, chemical, and physical characteristics of the ground water may depend directly on the proper 
functioning and relationship of the well and the septic tank disposal system. Improper construction of the well may cause foreign matter to enter the well and thus endanger the water supply. Likewise, improper placement of the well or septic tank disposal system may cause pollution of an individual's water supply by his own sewage or that of his neighbor. In many cases, compound problems may exist such as poor placement and faulty construction. Eighty-eight of the 157 wells tested were reported as allowing the entrance of surface material through the top of the well casing or some other imperfection in the well. Also, 76 samples showed that the sewage seepage system was located less than 100 feet from the well and/or on higher ground than the well. An improper relationship between the sewage disposal system and the well is often the primary cause of pollutants entering a ground water supply.

Because of the rural nature of portions of the Upper Pawcatuck River Basin, some scattered homes still depend on privies to dispose of their waste. An improper distance between the privy and the well or the improper placement could result in the pollution of the well by the underground travel of sewage from the privy to the well. The state Health Department reported that 31 samples of ground water showed that sewage from a privy was polluting the water in the well. In addition, Il samples showed that the location of the well in the basement of the building was unsafe. 
Finally, 9 samples exhibited the need for cleaning and repairing of the well in addition to chlorination of the water supply. It should be pointed out that many individual wells or disposal systems had more than one imperfection. Analysis of Public Well Data

In adition to providing a service of water analysis to individuals in the state requesting the service, the Rhode Island Department of Health also analyzes the wells of all public and institutional supplies whether a request is made or not. The analysis of wells of prblic and institutional water suppliers is much more extensive than the analysis conducted on individual supplies, since pollution of these supplies could endanger the health of a very large number of people. Although general conclusions and recommendations are not included in the written report of the findings, the concentrations of various chemical constituents found in the water supplies are reported. In addition, the written report of the findings does not give the results of the bacteriological examination. 59

In August 1968, the Rhode Island Department of Health released the findings of the chemical analyses of ground water supplies that serve the public and institutions in the state of Rhode Island. These findings were the result of analyses performed on samples of ground water collected

59 According to Mr. John Clifford of the Rhode Island Department of Health, Division of Water Supply Control, the bacteriological results for the public and institutional wells in the Upper Pawcatuck River Basin showed no traces of pollution at the present time. 
during the period July 1, 1967 to June 30, 1968. The ground water supplies found in the Upper Pawcatuck River Basin that were analyzed are: Kingston Fire District ( 1 well), Wakefield Water Company ( 5 wells), Ladd School ( 2 wolls), and the University of Rhode Island ( 3 wells).

The concentrations of the various chemical constituents found in the ground water supplies generally were below the standards set down by the U.S. Public Health Service. The only supply that was reported to have a chemical substance in excess of the prescribed limit was that serving the University of Rhode Island. Two of the three wells supplying water to the University of Rhode Island contained manganese in excess of the recommended limit of 0.05 milligrams per liter $(\mathrm{mg} / \mathrm{l})$. One had a concentration of $0.9 \mathrm{mg} / \mathrm{l}$, while the other had $0.1 \mathrm{mg} / \mathrm{l}$. The source of the excess manganese may be in the soil through which water leaches in entering the wells.

Bxeept in very unusual circumstances manganese is not toxic. It is undesirable in domestic water supplies because it causes unpleasant tastes, deposits on food during cooking, stains and discolors laundry and plumbing fixtures, and fosters the growth of some micro-organisms in reservoirs, filters, and distribution systems. 60

60A.E. Griffin, "Problems Caused by Manganese in Water Supplies", Journal of the American Water Works Association, 50 (1958), $\frac{\text { Journ. }}{1386 .}$ 
Summary and Conclusions

From the preceding analysis, it may be concluded that widespread pollution of the ground water supply of the Upper Pawcatuck River Basin does not exist at the present time. The fact that most of the area is rural and sparsely developed has prevented the existence of an areawide ground water pollution problem. However, a serious ground water pollution problem may develop in the Basin as future development of the area takes place if the prosent means of disposing of sewage continues into the future.

There are several reasons why widespread ground water pollution may occur in the future. First, as was mentioned earlier, the northern portion of the Basin has till as its principal unconsolidated deposit. Since till consists of fragments ranging in size from clay particles to boulders, pollutants introduced into this material are likely to travel much greater distances than those introduced into the outwash deposits. Since pollution travels farthest in the direction of ground water flow, the danger of polluting the ground water reservoirs in the central part of the Basin exists due to the movement of ground water from north to south.

A second reason why a serious ground water pollution problem may occur as development increases in the future is the fact that throughout most of the Basin the depth to the ground water is relatively shallow. Generally, the water table is within 10 feet of the land surface, while in the 
area of the Great Swamp, the water table is at or near the surface. 61 The existence of a high water table allows little time for sewage effluent to percolate through the zone of aeration where maximum purification of water occurs. In adition, movement of pollutants is generally much greater just below the water table, where most pollutants occur, than at greater depth.

The majority of the private wells in the Basin are dug wells, which are especially susceptible to contamination because of their large diameter and the associated difficulties in sealing them properly from surface contaminants such as polluted water, sewage, mbbish, and decaying vegetation. If dug wells continue to be the most desirable moans of obtaining water for private use, then the danger of the water in these wells becoming polluted will continue to be a major concern throughout the Basin.

Finally, evidence exists to support the fact that the soll characteristics in much of the area of the Upper Pawcatuck River Basin may be unsuitable for private sewage disposal facilities. The need for public sewage facilities in the highly developed adjoining communities of Wakefield and Peacedale has been recognized for many years. 62 Also, the large percentage of individual wells that have shown

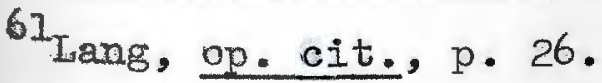

62 Report to the South Kingstown, Rhode Island Planning Beard Upon Sewage Facilities Required in the WakefieldPeacedale Area (Boston: Metcalf and Eddy, Engineers, I958), p. I. 
the presence of various pollutants indicates that septic tanks may not be an acceptable means of sewage disposal, especially in areas where development becomes dense. As development takes place in the Basin, the rate of pollution may very well be greater than the rate of growth if private water supply and sewage disposal facilities are placed on lots too small to properly accomodate them. 
VII

DEVELOPMENT COSTS OF SEWAGE

DISPOSAL AND WATER SUPPLY FACILITIES

The various reasons for the possible future occurrence of widespread ground water pollution in the Upper Pawcatuck River Basin have been discussed in the preceding chapter. The most dangerous source of ground water pollution has been shown to be the sewage that enters the ground through the use of septic tank and cesspool disposal systems on individual lots. A means of eliminating this hazard would be the development of a municipal or regional sewage treatment system.

This chapter is concerned not only with the development costs of a regional sewage treatment and disposal system, but also with the development costs of alternative means of water supply: ground water and surface water. It is hypothesized that savings can accrue to the Upper Pawcatuck River Basin region in the long run through the development of the ground water reservoirs found in the Basin, together with a regional sewage treatment and disposal system to eliminate the sewage that is presently being disposed of below ground. These savings would occur as a result of eliminating the development costs associated with a surface water supply that would be necessary if the present ground water supply should become polluted. The sum of the cost of the sewage treatment and disposal system and the cost of a large scale well development for the area will be compared with the development 
cost of a surface impounding reservoir to determine if the well development plus the sewage disposal system represents a savings over the costs associated with the development of a surface impounding reservoir.

Inadequacy of Private Sewage Disposal Facilities

In suburban areas where muicipal facilities are lacking, the construction of homes requires that water suppIy and sewage disposal facilities be developed on the same lot. However, the placement of these facilities on a small home lot represents conflicting uses of the land. From the well data analyzed in the previous chapter, it is clear that many individuals' water supplies in the Jpper Pawcatuck River Basin have been harmed due to the improper placement of the sewage disposal system and/or the well.

The typical home waste water disposal system has three components. The first component, the septic tank, is a concrete tank which acts as a trap for all solids so that bacteria may break down the material. Today's homes usually have septic tanks with a capacity of at least 900 gallons. The second component of the home waste water disposal system is the distribution box, and its function is to spread the liquified wastes into the surrounding soil. Finally, the leaching or seepage system is the area where the waste liquid enters the soil. Figure 7 shows diagrammatically a typical septic tank disposal system. It also shows a cesspool 

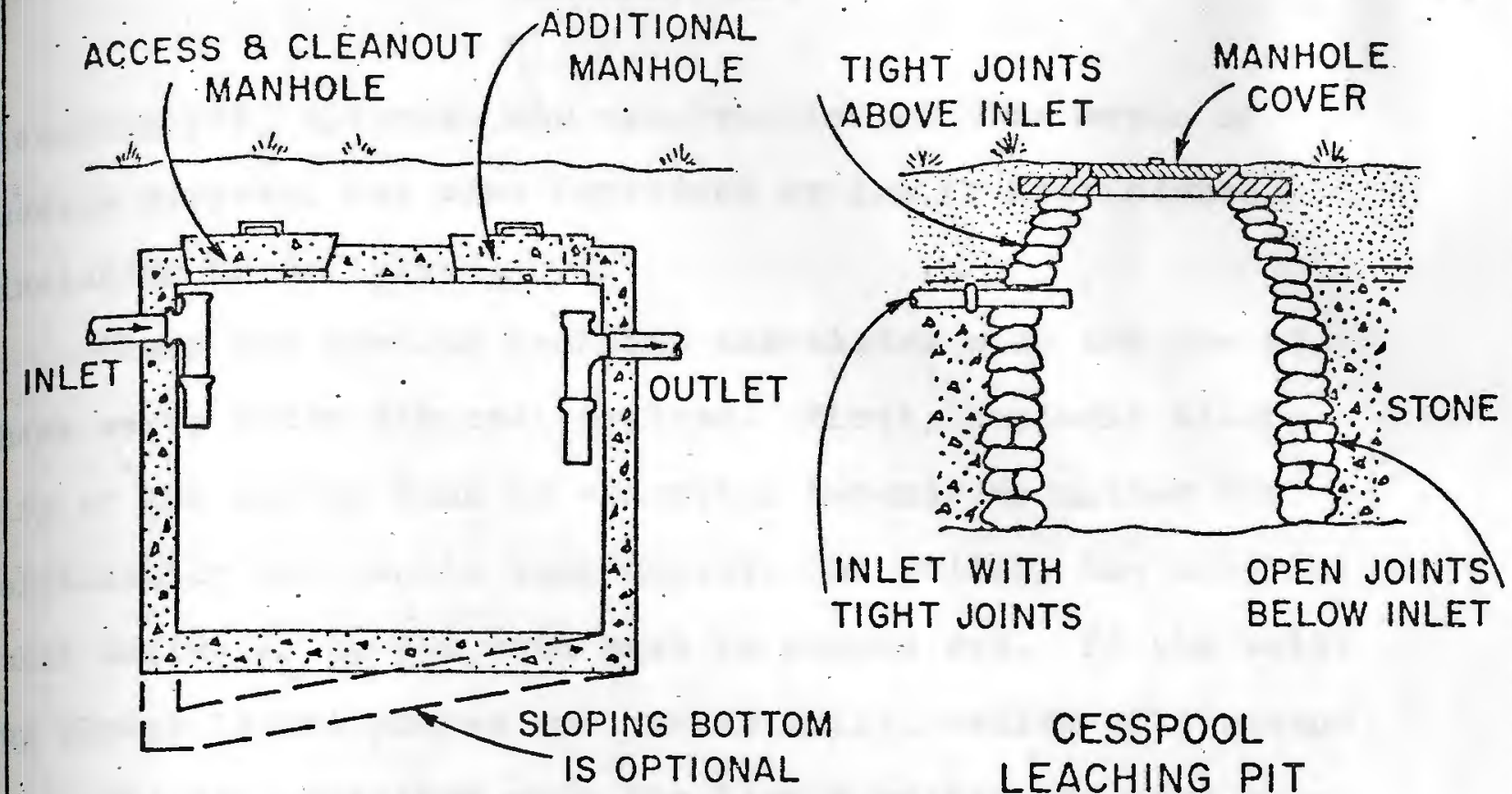

SEPTIC TANK

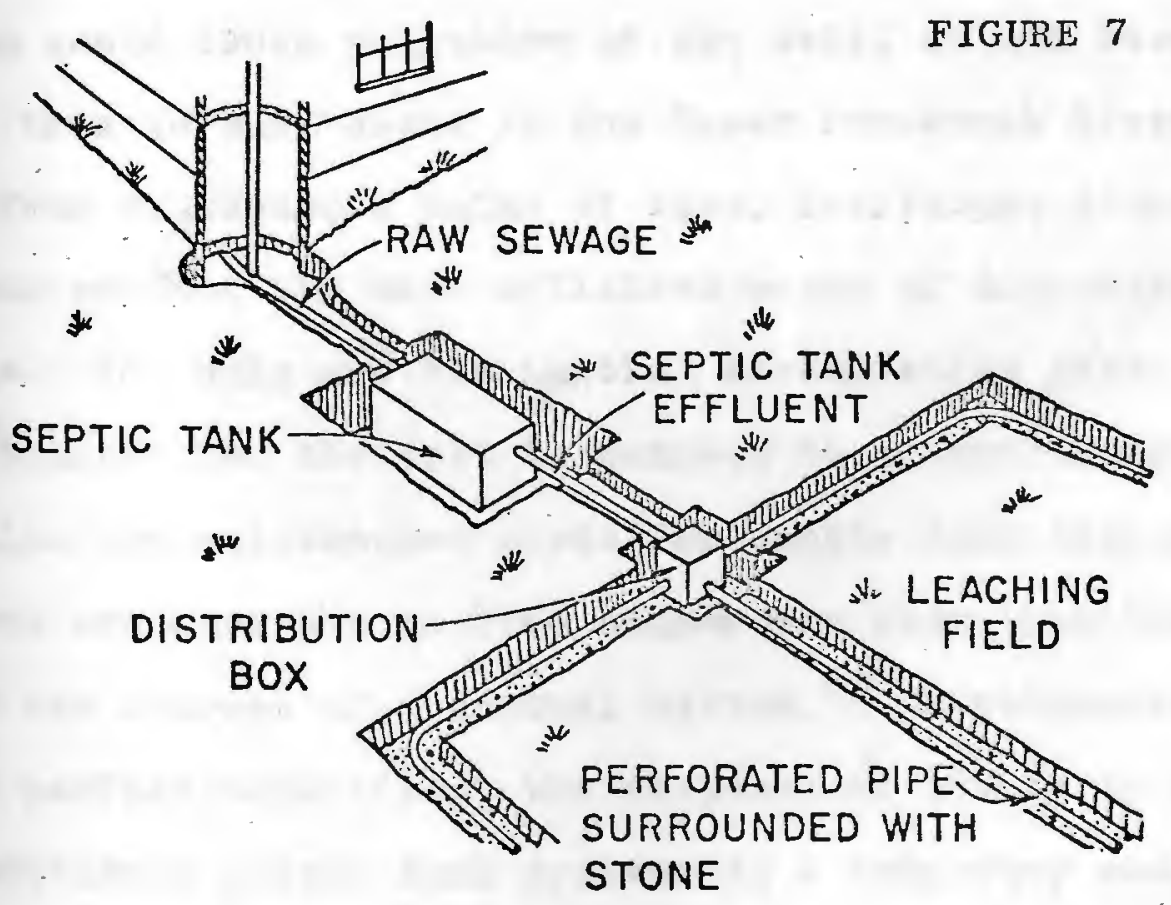

SEPTIC TANK SEWAGE DISPOSAL SYSTEM

\section{PRIVATE, ON-LOT SEWERAGE SYSTEMS}

Source: Metcalf \& Eddy, Engineers 
leaching pit, although new construction of this means of sewage disposal has been forbidden by law in most states neluding Rhode Island.

There are serious problems associated with the use of home waste water disposal systems. First, periodic eleaning of the septic tank is essential because no matter how Aricienty the septic tank digests the solids, the material that builds up in the tank mast be pumped out. If the built up sludge is not pumped out periodically, solids will escape from the tank together with the liquid wastes and pose a potential pollution hazard for the ground water. Furthermore, the improper location of the septic tank disposal system could cause pollution of the well, as has been found to be true in many cases in the Upper Pawcatuck River Basin. From an economic point of view, individual disposal systems are not the most efficient means of disposing of sowage. Not only are the initial installation costs generally higher than the cost to connect to a central system, but also the maintenance costs for septic tank disposal systems are from $\$ 40$ to $\$ 100$ higher per jear than the normal sewer use charges of a central system. 63 Furthermore, even under perfect conditions, the disposal of sewage by means of individual septic tank systems is a temporary measure. Not only will the septic tank disposal system fail in the long run functionally, but also areas where development

${ }^{63}$ Intergovernmental Responsibilities for Water Supply and Sewage Disposal in Metropolitan Areas (Washington: Advisory Commision on Intergovernmental Relations, 1962), p. 26 . 
becomes dense will eventually require the abandonment of private sewage disposal facilities and connection with a municipal or regional sewage treatment and disposal system due to the considerable land area necessary for these systems to operate properiy.

Development Costs of a Regional Sewage Treatment and Disposal System

In 1968, Charles A. Maguire \& Associates of Providence prepared a report for the town of Narragansett proposing waste water collection and disposal facilities when it was found that the existing public sewage treatment and disposal facilities did not meet the general needs of the state to preserve the shorelines and reduce pollution. 64 In the report, joint facilities with the town of South Kingstown and the University of Rhode Island were recomended since the town of Narragansett would find it difficult to support financially such a venture independently.

The need for sewage treatment and disposal facilities for the Wakefield-Peacedale area of South Kingstown has been recognized for a long period of time. In addition, although the University of Rhode Island has its own sewage treatment and disposal facility, the plant is overutilized. The University is presently increasing the capacity of its sewage treatment plant by $50 \%$. However, even with the expansion, the plant will not be able to accomodate any additional sewage

64 Report on Waste Water Collection and Disposal Facilities for the Town of Narragansett, Rhode Island (Providence: Charles A. Maquire \& Associates, Bngineers, 1968), p. 6 . 
over the expected amount to be treated in 1972. The University's sewage treatment plant will not be able to be enlarged further because the effluent from the plant discharges into a brook which flows west from the campus into Wordens Pond. The formation of algae on the pond has become a serious concern of homeowners in the area. This pollution problem has been publicized in the local newspaper and has become a concern of state officials.

Lt. Gov. J. Joseph Garrahy authorized an investigation of a thick, green algae which this year covered most of Wordens Pond, and which area residents fear may destroy the waterway before a proposed regional sewer system can be constructed. The Wordens Pond Homeowners' Association which brought the complaint to the lieutenant governor, charged that algae are being nourished by effluent from the University of Rhode Island sewer plant. 65

In June 1969, a plan was approved for the development of a combined sewage treatment plant and outfall system that would initially serve the town of Narragansett; the villages of Wakefield, Peacedale, and Kingston in the town of South Kingstown; and the University of Rhode Island. Figure 6 is a schematic representation of a system such as the one that has been approved, while Table 14 shows the cost associated with the development of such a system. These costs do not include the cost of the lateral lines. The cost of the lateral lines was exeluded because the development costs of the ground water supply and surface water reservoir do not Include the cost of tying individual homes into the supplies.

${ }^{65}$ The Narragansett Times, November $20,1969, \mathrm{p} .1$. 


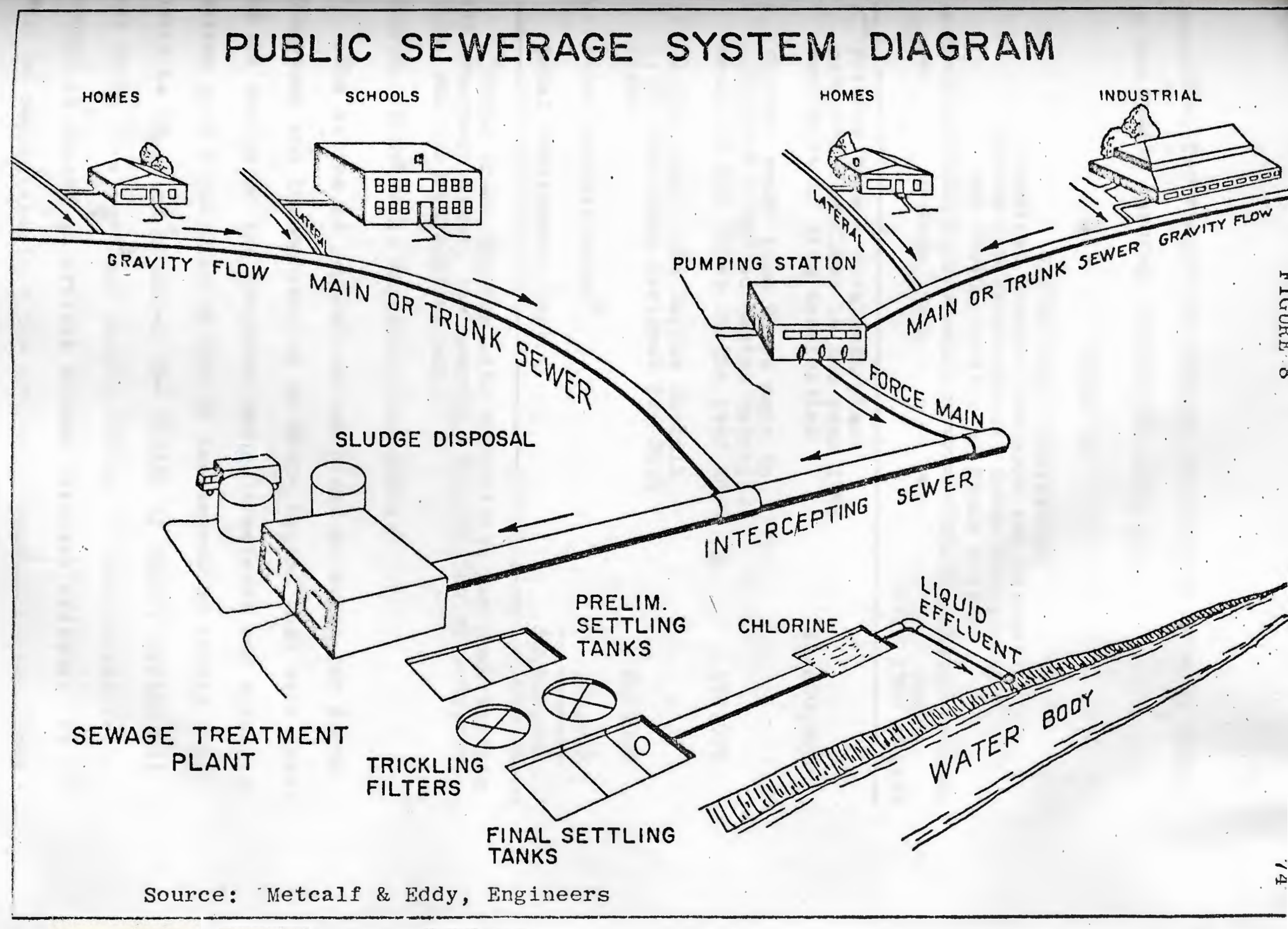


Therefore, for comparison reasons the cost of lateral lines in the public sewerage system was left out.

\section{TABLE 14}

SYSTEM COST ITEMIZATION

(Combined Sewage Treatment and Disposal

System for Narragansett, South Kingstown,

and the University of Rhode Island)

\section{Item}

Cost

July 1968 prices

1. Primary sewage treatment plant

designed for flows in the year 1995

exclusive of site acquisition

$\$ 1,800,000$

2. 24-inch sewer from force main to

treatment plant to Marine Outfall--

designed for flows in the year 2020

180,000

3. 24 -inch cast iron Marine Outfall

1,350 foot long designed for 2020

flows

200,000

4. Other project costs

320,000

Total Development Cost

$\overline{\$ 2,500,000}$

ather costs include site acquisition for pump station and treatment plant, engineering, supervision of construction, and project contingeney.

Source: Charles A. Maguire \& Associates

The estimated population and flows of waste for South

Kingstown and the University of Rhode Island that were used in the design of the proposed sewage treatment and disposal system give a good indication of the amount of sewage that could be expected to enter the ground if such a system was not to be developed and people living in these areas continued to depend on private sewage disposal systems. It must be emphasized that the projected population and flows 
are only for a very small portion of the Basin. In the future, other areas may be serviced by tying into the proposed system. Furthermore, it should be emphasized that the Ilquid effluent from the regional treatment plant will not be returned to the ground water supply, but will rather be discharged into Narragansett Bay, thus leaving the ground water supply in a naturally pure state. Table 15 shows the projected population and waste water flows that were used in the design.

\section{Welopment Costs of a Large Scale Ground Water Supply}

The development of a large scale municipal well system in the Jpper Pawcatuck River Basin can be advocated for several reasons:

1. Well water developments on individual lots are a short run method of providing an adequate supply of water. As further development takes place, some-areas of the Basin may not be capable of yielding a sufficient quantity of water. e.g. areas underlain by bedrock.

2. There exist two extensive ground water reservoirs in the central part of the Upper Pawcatuck River Basin that are capable of supplying water not only to the commities in the Basin itself, but also to surrounding areas.

3. A municipal water supply system could be a tool for planning the future development of the Basin by 


\section{TABLE 15}

ESTIMATES OF SEWERED POPULATION AND AVERAGE FLOW FOR PART OF THE TOWN OF SOUTH KINGSTOWN AND THE UNIVERSITY OF RHODE ISLAND

\begin{tabular}{|c|c|c|c|c|c|c|c|}
\hline \multirow{2}{*}{\multicolumn{2}{|c|}{ Region }} & \multicolumn{2}{|c|}{1970} & \multicolumn{2}{|c|}{1995} & \multicolumn{2}{|c|}{2020} \\
\hline & & Pop. & $\begin{array}{l}\text { Flow } \\
\text { (mgd) }\end{array}$ & Pop. & $\begin{array}{l}\text { Flow } \\
\text { (mgd) }\end{array}$ & Pop. & $\begin{array}{l}\text { Flow } \\
\text { (mgd) }\end{array}$ \\
\hline \multirow[t]{3}{*}{ A. } & Winter & & & & & & \\
\hline & South Kingstown ${ }^{a}$ & 7,500 & 0.90 & 11,000 & 1.50 & 14,600 & 2.20 \\
\hline & University ${ }^{b}$ & $11,070^{\circ}$ & 1.11 & 16,000 & 1.60 & 18,000 & 1.80 \\
\hline \multirow[t]{3}{*}{ B. } & Summer & & & & & & \\
\hline & South Kingstown & 7,500 & 0.90 & 11,000 & 1.50 & 14,600 & 2.20 \\
\hline & University ${ }^{e}$ & 7,400 & 0.74 & 10,600 & 1.06 & 12,000 & 1.20 \\
\hline \multirow[t]{3}{*}{ c. } & Annual Average & & & & & & \\
\hline & South Kingstown & 7,500 & 0.90 & 11,000 & 1.50 & 14,600 & 2.20 \\
\hline & University $^{d}$ & 10,200 & 1.02 & 14,600 & 1.46 & 16,500 & 1.65 \\
\hline
\end{tabular}

athis is the population estimated to be living in the areas of Wakefield, Peacedale, and Kingston for whom sewers are being considered.

Gris is the "Campus Population" and is composed of all enrolled undergraduate students; staff and faculty, taken according to the University of Rhode Isl and analysis as 23.5 per 100 resident undergraduates; and graduate students.

This population is taken as $2 / 3$ of the winter population. With sumer school, conferences and permanent stafe, the campus remains generally "full", except for fraternity and sorority houses according to campus authorities.

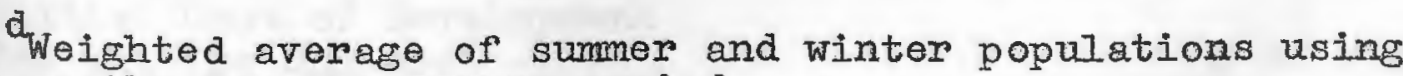
three months for the sumer period.

Source: Charles A. Maquire \& Associates 
providing water to particular areas where development is dosired.

As was mentioned in an earlier chapter, even though the privately owned Wakefield Water Company is the largest supplier of water in the Upper Pawcatuck River Basin, the majority of households in the Basin depend on individual wells for their water. Table 16 shows the development costs associated with a public well system, developed by the Wakefield Water Company, that is capable of yielding 1.6 million gallons of water per day at a development cost of $\$ 147,500$

TABLE 16

DEVELOPMENT COSTS OF A 1.6 MGD WELL SYSTEM DEVEIOPED IN 1966

Item

Cost

1. Exploration for water

$\$ 12,500$

2. Purchase of land 27,250

3. Building and equipment 25,000

4. Well construction 15,750

5. Transmission line to tie into the present system

67,000

Total Development Cost $\$ 147,500$ Initial Cost of Development Per Million Gallons $\$ 92,200$

Source: Wakefield Water Company 
In 1965, Mr. Paul R. Farragut estimated the costs involved in developing a large scale ground water supply in the Upper pawcatuck River Basin. 66 Table 17 shows the costs associated with such a development at that time. The estimated initial development cost of this 25 million gallon per day ground water development was $\$ 3,824,256$ or an estimated initial cost of development of $\$ 152,970$ per million gallons of water.

\section{TABLE 17}

PROBABLE INITIAL DEVELOPMENT COSTS ASSOCIATED WITH A 25 MGD WELI DEVELOPMENT IN THE UPPER PAWCATUCK RIVER BASIN

\begin{tabular}{|c|c|c|}
\hline & Item & Cost \\
\hline 1. & Land--30 acres at $\$ 2,000$ per acre & 60,000 \\
\hline 2. & Pipeline between two well fields & 60,000 \\
\hline 3. & 40 test wells at $\$ 2,000$ per hole & 80,000 \\
\hline & $\begin{array}{l}30 \text { supply wells including pump and } \\
\text { well houses at } \$ 50,000 \text { each }\end{array}$ & $1,500,000$ \\
\hline & $\begin{array}{l}\text { Pipe costs involved in tying the wells } \\
\text { together and trunk lines to standpipe } \\
\text { (cost of standpipe not ineluded) }\end{array}$ & $1,496,880$ \\
\hline & & $\$ 3,196,880$ \\
\hline 6. & $\begin{array}{l}\text { Engineering and contingencies not } \\
\text { including land }\end{array}$ & 627,376 \\
\hline & Total Development Cost & $\$ 3,824,256$ \\
\hline & $\begin{array}{l}\text { Estimated Initial Cost of Development } \\
\text { Per Million Gallons }\end{array}$ & $\$ \quad 152,970$ \\
\hline
\end{tabular}
costs.

Assumed to be 20 percent of expenses excluding land

Source: R. E. Chapman Company, United States Geological Survey, and Kent County Water Authority.

${ }^{66}$ Paul Robert Farragut, "Economics of Use and Distribution of Water in Rhode Island" (unpublished Master's thesis, Department of Food and Resource Economics, University of Rhode Island, 1965), p. 99. 
Qvelopment Costs of a Surface Water Supply

If a regional sewage treatment and disposal system were not developed for the Upper Pawcatuck River Basin region, the continued placement of individual wells and septic tank disposal systems on the same lot would pose a potential widespread pollution threat to the ground weter. Should the ground water in the Basin become polluted to the point that it could not be used for human consumption, an alternative means of supplying water to the area would be the development of a surface water reservoir.

In his thesis, Mr. Farragut presented the estimated costs associated with the development of a surface impoundIng reservoir that could safely yield 26.4 million gallons of water per day. The basis for his development costs was a study conducted by Metcalf and Eddy Fingineers of Boston. 67 According to Mr. Farragut's calculations, the estimated cost of developing this surface reservoir would be between $\$ 9,789,190-\$ 10,649,190$, with the variation in total development cost being due to different land cost estimates. A later report revised the total cost to be between $\$ 8,152,226$ and $\$ 9,012,226.68$

In 1967, a new study was prepared by Metcalf and Eddy Engineers in which updated data were presented for the same

67 Feasibility of Development of Water Supply Resources of Rhode Island (Boston: Metcalf and Eddy Fingineers, August, 1957).

68 Arthur D. Jeffrey, Economics of Water Supply in Rhode Island, Agricultural Experiment Station Misc. Pub. 62 (Kingston: University of Rhode Island, July, 1966), p. II. 
reservoir. 69 Using the data from this study, it was estimated that the proposed reservoir would have a safe jield of 26.0 million gallons of water per day at a total development cost of approximately $\$ 11,592,000$. (See Table 18)

\section{TABLE 18}

DEVEIOPMENT COSTS ASSOCIATED WITH THE BIG

RIVER SURFACE IMPOUNDING RESERVOIR

Item

Cost

1967 Prices

1. Land acquisition ${ }^{2}$

$\$ 4,300,000$

2. Clearing and grubbing

$1,400,000$

3. Demolition of structures

70,000

4. Cemetery relocation

60,000

5. Highway relocations

$1,295,000$

6. Public utility relocations

200,000

7. Dams, dikes, and appurtenant works

$2,330,000$

8. Engineering and contingencies

$1,937,000$

Total Development Cost

$\$ 11,592,000$

Estimated Initial Cost of Development Per Million Gallons

$\$ \quad 400,000$

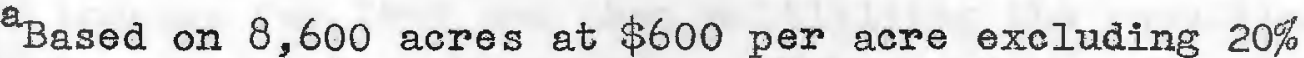
for engineering and contingencies. This land has already been purchased.

Source: Data from Metcalf and Eddy Report of 1967

69 Report to the Water Resources Coordinating Board, State of Rhode Island, on a Development Plan for the Water Supply Fe sources of Rhode Island (Boston: Metcals and Eddy Engineers, (ugust, 1967). 
Comparison of Development Costs

The hypothesis of this study was that there exists an economic advantage in developing the ground water reservoirs located in the Upper Pawcatuck River Basin, together with a pegional sewage treatment and disposal system to eliminate the sewage that is presently being disposed of below ground. Beonomic savings would occur as a result of eliminating the development costs associated with a surface water supply that would be necessary if the ground water supply should become unsafe for human consumption.

In order to compare the development costs of the regional sewage treatment and disposal system and the ground water development with the costs of the surface water development, it was necessary to bring the development costs presented earlier in this chapter up to date. The development costs presented in Table 14 for the sewage treatment and disposal system were based on July 1968 prices and therefore had to be updated. This was done by taking the 1968 sewage treatment plant cost index and 1968 sewer construction cost index in Fngineering News-Record and dividing them into the appropriate indexes for 1969 and then multiplying the resulting factors times the previous costs for the individual items. 70 As can be seen from Table 19, the updated development cost for the sewage treatment and disposal system was $\$ 3,040,000$.

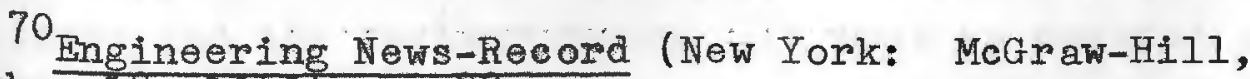
December 18, 1969), p. 88 . 
This updated figure represents a $21.6 \%$ increase over the development cost given in 1968.

\section{TABLE 19}

UPDATED SYSTEM COST ITEMTZATION (Combined Sewage Treatment and Disposal System for Narragansett, South Kingstown, and the University of Rhode Island)

Item
July 1968 october 1969
prices prices

1. Primary sewage treatment plant designed for 1995 flows-exclusive of site acquisition $\$ 1,800,000 \$ 2,200,000$

2. 24-inch sewer from force main to treatment plant to Marine Outfall-designed for 2020 flows $180,000 \quad 220,000$

3. 24-inch cast iron Marine Outfall 1, 350 foot long designed for 2020 flows prices prices

4. Other project costs ${ }^{2}$

Total Development Cost

$\begin{array}{rr}200,000 & 226,000 \\ 320,000 & \frac{390,000}{\$ 2,500,000} \\ \$ 3,040,000\end{array}$

ather costs include site acquisition for pump station and treatment plant, engineering, supervision of construction, and project contingency.

Source: Charles A. Maguire \& Associates and Indexes from Engineering News-Record

Since the development costs for a $25 \mathrm{mgd}$ well development were given in 1965 prices, it was necessary to update these Itgures also. According to R. E. Chapman Company who quoted the development costs in 1965, 20\% had to be added to the 1965 estimate. 71 Table 20 shows the previously quoted development costs and the revised costs. It must be pointed out that

${ }^{71_{\text {See }}}$ the letter from Mr. Richard W. Sullivan of the R. E. Chapman Company found in the Appendix. 
in 1965 the land acquisition was estimated at $\$ 2000$ per acre for 30 acres or $\$ 60,000$. This was a very liberal estimate, since the land needed for the well development is primarily used for growing potatoes. In updating the development costs, a $20 \%$ increase was applied to all of the items including the cost of land acquisition. Thus, the updated estimate for land acquisition still remains a very liberal estimate.

\section{TABLE 20}

UPDATED PROBABLE INITIAL DEVELOPMENT COSTS ASSOCIATED WITH A 25 MGD WELL DEVELOPMENT IN THE UPPER PAWCATUCK RIVER BASIN

Item

\section{Cost}

1965 prices 1969 prices

1. Land-- 30 acres

$\$ 60,000$

$\$ 72,000$

2. Pipeline between two well fields

60,000

72,000

3. 40 test wells

80,000

96,000

4. 30 supply wells including pump and well houses

$1,500,000$

$1,800,000$

5. Pipe costs involved in tying the wells together and trunk lines to standpipe

$1,496,880$

$1,796,256$

6. Engineering and contingencies not including land $\frac{627,376}{\$ 3,824,256} \quad \frac{752,851}{\$ 4,589,107}$

Total Development Cost

Estimated Initial cost of Development Per Million Gallons $\$ 152,970 \$ 183,564$

Source: R. E. Chapman Company, United States Geological Survey, and Kent County Water Authority. 
The development costs associated with the Big River Surface Impounding Reservoir also had to be updated, since the Metcalf and Eddy Report used prices for 1967 in arriving at an estimate of the total development cost. The Metcalf and Eddy Report used a construction cost index of 1000 in arriving at the costs in 1967, while the Engineering NewsRecord Construction Cost Index in December 1969 was 1313.72 Therefore, all of the expenses in 1967 prices were maltiplied by 1.313, with the exception of "land acquisition" and "engineering and contingencies". Since the land for the reservoir has already been purchased, the land cost was not changed. The cost of engineering and contingencies was computed as $20 \%$ of the other costs. Table 21 shows the development costs in 1967 and also the development costs in 1969 for the Big River Surface Impouding Reservoir. The total development cost for the surface impounding reservoir increased from $\$ 11,592,000$ in 1967 to $\$ 13,612,800$ in 1969 . This represents approximately an $18 \%$ increase in development costs between 1967 and 1969.

The reason that information for the Big River Surface Impounding Reservoir was used in this study was the fact that the dependable yield was almost exactly the same as that of the well development in the Upper Pawcatuck River Basin. The Upper Pawcatuck River Basin well development would be located in the southern part of the state, while the surface reservoir was proposed to be developed north of the Upper Pawcatuck River Basin in the towns of West Greenwich and Coventry.

72 Engineering News-Record, op. cit., p. 80. 
Table 22 gives a comparison of development costs between the ground water supply and the surface water supply. The total development cost of the Upper Pawcatuck River Basin Ground Water Supply was $\$ 4,589,107$, while the total development cost of the Big River Reservoir Surface Supply was $\$ 13,612,800$ with both supplies yielding about the same amount of water.

\section{TABLE 21}

UPDATED DEVELOPMENT COSTS ASSOCIATED WITH THE BIG RIVER SURFACE IMPOUNDING RESERVOIR

\begin{tabular}{|c|c|c|c|}
\hline & Item & Co & \\
\hline & & 1967 prices & 1969 prices \\
\hline 1. & Land acquisition & $\$ 4,300,000$ & $\$ 4,300,000^{a}$ \\
\hline 2. & clearing and grubbing & $1,400,000$ & $1,840,000$ \\
\hline 3. & Demolition of structures & 70,000 & 92,000 \\
\hline $4 \cdot$ & Cemetery relocation & 60,000 & 79,000 \\
\hline 5. & Highway relocations & $1,295,000$ & $1,700,000$ \\
\hline 6. & Public utility relocations & 200,000 & 263,000 \\
\hline 7. & $\begin{array}{l}\text { Dams, dikes, and appur- } \\
\text { tenant works }\end{array}$ & $2,330,000$ & $3,070,000$ \\
\hline 8. & $\begin{array}{l}\text { Engineering and contin- } \\
\text { gencies }\end{array}$ & $1,937,000$ & $2,268,800$ \\
\hline & Total Development Costs & $\$ 11,592,000$ & $\$ 13,612,800$ \\
\hline & $\begin{array}{l}\text { Estimated Initial Cost of } \\
\text { Development Per Million } \\
\text { Gallons }\end{array}$ & 400,000 & 516,000 \\
\hline
\end{tabular}

aland had already been purchased.

Source: Metealf and Eddy Fingineers and Engineering NewsRecord Construction Cost Indexes. 
COST COMPARISON BETWEEN DEVELOPMENT COSTS OF THE UPPER PAWCATUCK RIVER BASIN GROUND WATER SUPPLY AND THE BIG RIVER RESERVOIR SURFACE SUPPLY (1969 Prices)

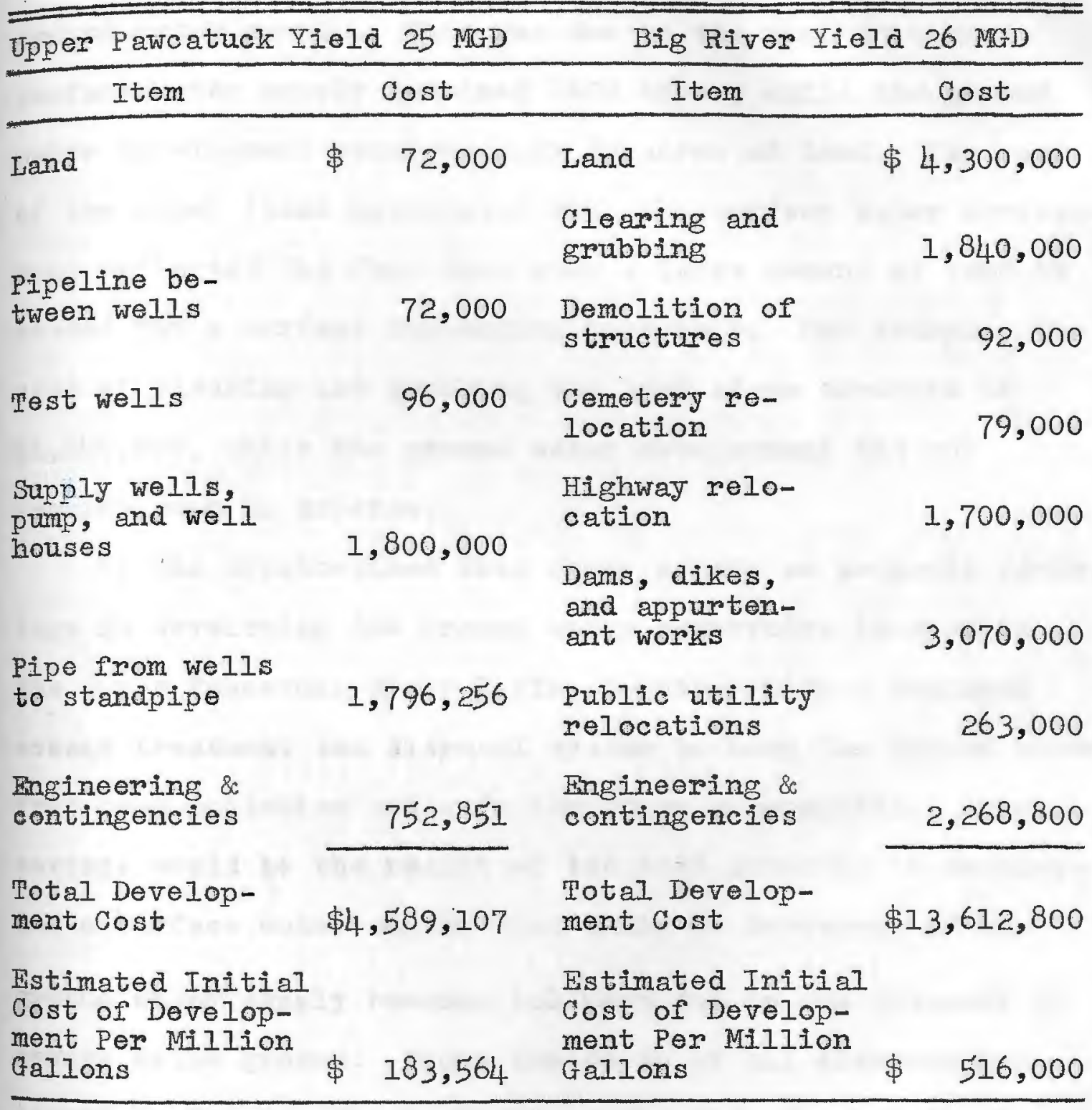

The largest variation in the costs of the individual items in the development of the ground water or surface water supply appeared in the "land acquisition" item. Although the cost of land necessary for a ground water development 
was liberally estimated at $\$ 72,000$ for 30 acres, the total cost of land for the surface water supply amounted to $\$ 4,300,000$ or $\$ 4,228,000$ more than the land cost for the ground water supply. This was due to the fact that the surface water supply required 8600 acres, while the ground water development required only 30 acres of land. The cost of the other items associated with the surface water development reflected the fact that such a large amount of land is needed for a surface impounding reservoir. For example, the cost of clearing and grubbing the land alone amounted to $\$ 1,840,000$, while the ground water development did not require such an expense.

It was hypothesized that there exiats an economic advantage in developing the ground water reservoirs located in the Upper Pawcatuck River Basin, together with a regional sewage treatment and disposal system to keep the ground water free from pollution and safe for human consumption. These savings would be the result of the cost involved in developIng a surface water supply that would be necessary if the ground water supply becomes polluted due to the disposal of sewage below ground. Since the costs of all elements mentioned in the hypothesis had been updated, the hypothesis could be tested. Development costs for the various systems were the following: 
Upper Pawcatuck Ground Water Development \$4,589,107

Big River Surface Impounding Reservoir \$13,612,800

Sewage Treatment and Disposal System $\$ 3,040,000$ The combined total development cost for the ground water development and sewage treatment and disposal system was $\$ 7,629,107$, while the cost of developing the surface water reservoir amounted to $\$ 13,612,800$. Thus, the cost of the surface water development was $\$ 5,983,693$ greater than the development cost of the ground water supply and sewage treatment and disposal system combined. The development of the ground water supply and sewage treatment and disposal system represents a $44 \%$ saving over the cost of developing a surface water supply that would jield approximately the same amount of water. Thus, the hypothesis of the study has been tested and verified. 


\section{VIII}

\section{PLANNING IMPLICATIONS}

whis study has indicated that the development costs associated with a large scale ground water development and a regional sewage treatment and disposal system are less than the development cost of a surface impounding reservoir that would yield approximately the same amount of water. Thus, the concern has been not only with alternative methods of water supply, but also with the quality of water supplied. It was assumed that the water would be used primarily for human consumption, since this use requires water of the highest quality.

It is the purpose of this chapter to examine some of the problems encountered in supplying an area with an adequate supply of water suitable for human consumption, and in disposing of the sewage that may pollute that supply. Since this study has been concerned wholly with capital costs, an explanation of the other land development costs will be given together with a very general explanation of the use of benefit-cost analysis in the planning of water resource developments. Finally, the benefits of comprehensive water and sewage development will be given, together with the role of planning in that development. 
Problems at the Loeal Level

In order to arrive at some conclusions as to how suburban communities may be adequately supplied with pure water through a publicly operated water supply system, it is necessary first to examine the problems that have traditionally grisen. The first and most serious problem of water supply and sewage disposal at the local level has been inadequate investment in these facilities. As in the case of the town of South Kingstown, the members of the conmunity had been unwilling for 10 years to accept the initial cost of a sewage treatment and disposal system. A regional system serving parts of the towns of Narragansett and South Kingstown and the University of Rhode Island was approved 10 years after it was discovered that: (1) Narragansett's small system was not adequately treating the sewage; (2) private sewage disposal systems in the Wakefield-Peacedale area of South Kingstown were failing; and (3) the University of Rhode Island system could not accomodate any additional sewage after 1972. Thus, the heart of the problem of inadequate investment has been the communities' reluctance to increase local expenditures in order to prevent the pollution of the shore areas, but more importantly to prevent the pollution of the ground water supply on which the area is presently dependent. Only when the pollution problem had become serious was the system approved. 
A second problem that has arisen in the provision of water supply and sewage disposal facilities at the local lovel has been that of fragmentation. Fragmentation of facilities for each locality has been due to each community's desire to maintain control over its local tax rate. Very seldom have individual suburban communities been willing to take part in a water or sewerage system that could lead to their financing utility provisions for some other community. Suburban communities are always fearful of the higher taxes that are paid in the central city where these services are provided on a large scale.

Where utility districts have been formed in suburban areas, they have tended to be small since these districts are set up on a "user pay" principle and therefore have a linited service area. Since these districts are formed in areas of population concentration, a region may have several areas of population concentration with each area having its own municipal water supply or sewage disposal district. This has resulted in a large number of water supply or sewage disposal systems within a region with very little or no coordination between systems.

Fragmentation of facilities in suburban areas may be attributed to the lack of planning and coordination between communities. Small sewage disposal systems often have not been designed with the future growth of the community in mind and as a result some have not been able to treat the sewage adequately. A good example is the situation that exists in 
the town of Narragansett, where it was discovered that the local sewage treatment and disposal system was not treating the sewage adequately. As a result, the town of Narragansett approved the development of a regional sewage treatment and disposal facility with the town of South Kingstown and the University of Rhode Island. A similar situation has occurred for the University of Rhode Island, which found that the effluent from its plant was causing the growth of algae in Wordens Pond and that the system would not be able to accommodate the sewage by 1972. Thus, a lack of planning and coordination will prove very costly due to the obsolescence of the small systems.

A parallel situation has existed in water supply where a suburban area has depended on individual wells and then either connects to an existing municipal system or develops its own. When the connection is made, the cost of constructing the well is one that cannot be recovered. The existence of a number of small muicipal water supplies or private water companies is also a problem of fragmentation, due to concentrations of population caused by uncontrolled development. Each supplier must develop its own water supply and distribution system often due to the lack of coordination between systems. This has occurred in the Upper Pawcatuck River Basin where there exist six water supplies providing water from their individual well supplies (see chapter III), with no coordination between or among systems. 
The Wakefield Water Company, a private regional distribution system, provides water to parts of South Kingstown and Narragansett. However, there were other parts of both towns which were in need of municipal water, but the Wakefield Water Company was not able to extend service into these areas. Traditionally, this has been due to the fact that private water companies are a part of the private enterprise system and therefore are able to extend service only to areas that promise the largest returns and must leave the more remote districts without a supply. As a result, Narragansett has been forced to develop its own municipal distribution system to serve areas in the southern and northern portions of the town, while the town of South Kingstown had to develop a small municipal water system to serve an area that is primarily seasonal in nature and offers little promise of an inmediate financial return to a private water company. The result has been a highly fragmented water supply situation, in which the Wakefield Water Company serves the central areas of Narragansett and South Kingstown, while other areas of both towns are supplied with water by small municipal systems. This fragmentation has produced a situation in which it is very difficult for any type of planning to occur.

A problem ariaing directly from the fragmentation of water supply and sewage disposal facilities has been urban sprawl. The housing boom that took place after World War II outside the central cities had a great affect on the pattern 
of land development. When new settlements were unable to connect to city water and sewer systems, it was necessary to find other water supply and sewage disposal facilities. Individual wells and septic tanks, which previously were only used in rural areas, were introduced in the new settlements. What resulted was that development began to spread out in scattered clusters, sometimes miles from the existing urban areas. This type of development left large areas of vacant land between the new settlements. To planners, this pattern of growth has come to be known as urban sprawl, and is responsible for the inefficient use of large land areas. The shortcomings of on-lot water supply and sewage disposal systems have already been examined in chapter VII; however, the effect on the pattern of land development and land cost from the use of these facilities must be explained. Individual disposal systems demand an area of considerably larger dimensions than the typical house lot connected to a sewerage system in order to provide for an acceptable absorption field. This has produced the need of providing a suburban home lot about three times larger than the typical lot of 15,000 square feet. Thus, suburban developments have often resulted in the inefficient use of large amounts of land. If the market demand for land in a particular area is large, the price of land will reflect the need of using a large portion of the lot for sewage disposal purposes. Other improvements such as streets, also mean a higher cost, since a development with large lots will require greater frontage 
for streets. Furthermore, when the development eventually connects to a municipal system, the unamortized portion of the cost of septic tank installation is lost, since the lines are usually in the rear yard and cannot be converted.

A central water supply is generally more desirable than individual wells. As suburban areas have been built up, individual wells have become less dependable as to the quantity and quality of the water supplied. The inclination in the suburbs has been to ignore the development of central water supply and sewage disposal facilities until the individual systems have proven to be inadequate and a serious well pollution problem has occurred.

Overview of Benefit-Cost Analysis

The comparative cost analysis of altemative means of water supply presented in this study included only the development cost associated with the two methods. These development costs included: (I) the purchase cost of acquiring the necessary amount of land for the particular development; (2) cost of supersession, which are the costs of removing any improvements, such as buildings, already located on the land; and (3) the construction cost of the new development. Since the development of land usually involves the passing of some duration of time, there exist what are known as time costs which must be considered in any type of land development. Although it was not the purpose of this study to analyze the time costs associated with the two alternative methods of 
water supply, it should be mentioned what these time costs include and how they might affect the two methods of water supply which were considered.

Time costs include two types of costs that are associated with the holding of land. The first, waiting costs, are those costs which arise between the time of the first outlay of capital and labor and the time when the investment can be put to actual use. Interest charges would be considered a waiting cost. The second time cost is what is known as ripening costs. Ripening costs consist of the carrying costs that are incurred until the land is put to the new use. The loss of tax revenue would be classified as a ripening cost. In addition to development or investment costs and time costs, there are the continuing costs of operation.

Since this study has been concerned with altemative methods of providing a water supply (ground water development with a sewage treatment and disposal system vs. surface water reservoir), there must exist a method of determining which alternative to choose. It has already been shown that the development or investment cost of the ground water supply with a sewage treatment and disposal system was far smaller than the development cost of the surface water reservoir. Therefore, if the decision to choose one of the two alternative methods of supplying pure water was based on development cost alone, then the ground water development with a sewage treatment and disposal system would be the logical choice. 
It should be made clear, however, that the decision to undertake a particular project verry rarely is made on the basis of development costs alone. For example, the cost difference between the two alternative methods of water supply could be greater if waiting and ripening costs were included in the comparison. The fact that the ground water system could be developed as needed by drilling additional wells, while the surface system must be developed all at once, may mean that the ground water system has an additional economic advantage over the surface system when waiting and ripening costs are considered. Later studies could investigate to see if this were actually true.

Of direct concern to this study is the fact that the surface reservoir would require 8600 acres of land, while the ground water development would need only about 30 acres. This is of particular significance when the concept of highest and best use is considered. Land resources are at their highest and best use when they are used in a manner that provides an optimum return to society. The return may be measured in strictiy monetary terms, in social values, or some combination of these. If the surface reservoir were developed, a large amount of land would be unavailable for other uses, since competition for the use of the land would cease once the land was taken out of the market place by a public agency. This in fact has occurred in the case of the Big River surface reservoir in Rhode Island. Since the concept of highest and best use is a pelative one, the debate 
whether the land would provide a better return in some other use or uses will continue.

The traditional method of deciding if and what water resource project should be undertaken has been through the use of benefit-cost analysis, Most benefit-cost studies in water resource development follow the procedures and criteria set down by the U.S. Federal Inter-Ageney River Basin Committee. 73 Although it is not the purpose of this study to subject the two alternative methods of water supply to a benefit-cost analysis, a general understanding of what this analysis encompasses would be helpful to any planner. Most of the following information on benefit-cost analysis is based on information from a book by Professor Raleigh Barlowe, titled Land Resource Economics. 74

The process of benefit-cost analysis is used to estimate the benefits and costs associated with resource development projects and to determine if the ratio of benefits to costs justifies the development of the projects. Standard benefitcost analysis identifies two types of benefits and three types of costs.

Primary benefits are those that result directly from a project, such as the provision of pure water to an area as the result of a regional ground water development and sewage

73. S. Federal Inter-Agency River Basin Committee, Proposed Practices for Economic Analysis of River Basin Projects (Washington: United States Govermment Printing Office, May, 1950).

74 Raleigh Barlowe, Land Resource Economies (Englewood Cliffs, N.J.: Prentice-Hall, Inc., 1958), pp. 484-492. 
treatment and disposal system. On the other hand, second or indirect benefits are those induced by a particular project which may increase values resulting from the primary objective of the project, Thus, the development of a central sewage treatment and disposal system would eliminate the need for septic tank systems, thereby increasing the value of the homes in the area served, since a central system is more dependable and the cost to the homeowner of disposing of his sewage is generally less in the long run. While some secondary benefits, such as increased land values, may be expressed in dollars, there may result intangible secondary benefits that can be identified but are not capable of simple expression in dollars, e.g. recreational benefits as the result of dam construction.

The three types of costs commonly recognized in benefitcost analysis are: (1) project costs, (2) associated costs, and (3) secondary costs. Project costs consist of the value of the land, labor, and materials that are necessary in developing and operating a project, plus an allowance for any undesirable effects that may result from the project. Associated costs include the value of any additional materials or services which may be needed to make the products or services of a project available for use or sale. Finally, secondary costs include the value of any goods or services in addition to project and associated costs that are used as a result of a project. They include the cost of processing any products or services which may result from a secondary 
benefit of a project. For example, the cost involved in operating a freight terminal which was built adjacent to a new highway would be considered a secondary cost.

Benefit-cost analysis involves more than just determining what the benefits and costs of a project are. Questions such as the following must be answered:

1. Is there an actual need for the project?

2. What is the best size of scale?

3. What is the most economic way of developing the project?

4. What portion, if any, of the costs are to be covered by user charges?

5. How can the costs of a project be apportioned among the separate commities within the area?

Although benefit-cost analysis is a useful tool in economic planning, there are shortcomings in the process. Since the technique for measuring secondary benefits and costs is somewhat vague, derived benefit-cost ratios often do not reflect the true worth of a project. Iikewise, the fact that some benefits and costs of a project cannot be assigned a dollar value results in benefit-cost ratios that disregard factors which should be considered in and decision to develop a particular project. Provided these shortcomings are understood, planning could benefit from the use of benefit-cost analysis. Whereas initially it was restricted primarily to water resource developments, benefit-cost analysis is now being used in other public land resource developments as well. 75

75 Performance of Urban Functions, Information Report No. M-2I revised (Washington: Advisory Commission on Intergovernmental Relations, September, 1963). 
Comprehensive Planning for Water Supply and Sewage Disposal

In addition to being an attempt at correcting problems that may exist in the present, plaming may be viewed as a process to foresee future requirements and to aim for the provision of those requirements in an economical fashion. Traditionally, water supply and sewage disposal have been developed and administered as separate functions by individual communities. Undesirable results such as urban sprawl have resulted from this practice. The fact that the two functions are so interrelated demands that they be considered as one service. Furthermore, because water has no regard for political boundaries and because of the economic benefits that could be realized by areawide planning, development of water supply and sewage disposal systems should be undertaken on a regional basis, which would serve areas of need and not necessarily watershed areas.

Economies of scale are the most convincing argument for the development of water supply and sewage disposal systems on a regional basis. The disadvantages of fragmentation have been discussed earlier in this chapter, and it was shown that small facilities have rarely provided a long-range solution to the water supply and sewage disposal problems. Table 23 shows how economies of scale are realized when sewage treatment plants are designed to serve large areas. The construction of a sewage treatment plant with a capacity of one million of gallons of sewage per day cost $\$ 415,000$ per million gallons of sewage, while a plant designed to accomodate 
100 million gallons per day cost only $\$ 135,000$ per million gallons of sewage. Similar economies of scale were realized in operation and maintenance costs and in the cost of providing sewage pumping stations.

\section{TABLE 23}

ESTIMATED UNITS COSTS OF CONSTRUCTION, OPERATION AND MAINTENANCE OF SEWAGE WORKS

FACILITIES--JANUARY, 1962 PRICES 76

Item

Cost of primary treatment

(per million gallons

of sewage)

Sewage treatment plant construction:

Plant with $100 \mathrm{mgd}$ capacity

$\$ 135,000$

Plant with $10 \mathrm{mgd}$ capacity

230,000

Plant with 1 mgd capacity

415,000

Operation and maintenance cost:

Plant with 100 mgd capacity

$\$ 23.00$

Plant with $10 \mathrm{mgd}$ capacity

27.00

Plant with 1 mgd capacity

44.00

Sewage pumping stations:

Plant with $50 \mathrm{mgd}$ capacity

Plant with $10 \mathrm{mgd}$ capacity

$\$ 11,000$

Plant with I mgd capacity

22,000

68,000

Although a city or community planner would not get involved in the technical aspects of water supply and sewage disposal, his role of shaping urban growth patterns cannot be accomplished without giving serious concern to the provisions

$$
{ }^{76} \text { Ibid., p. } 202 .
$$


of these utilities. Since these services exert an influence on the direction and rate of land development, their provision could be used effectively as a tool to implement desired development policies. Therefore, the planner should take an active part in the formulation of water and sewer plans by working directly with the engineer. The proper planning and provision of water supply and sewage disposal facilities is most important for encouragement of economical and orderly development of land for residential, industrial, and other purposes, since the type and location of water and sewerage facilities is a critical determinant of land use. 
BIBLIOGRAPHY 


\section{BIBLIOGRAPHY}

Allen, William B., Hahn, Glenn W., and Brackley, Richard A. Availability of Ground Water, Upper Pawcatuck River Basin, Rhode Island. Geological Survey Water Supply Paper 1821. Washington: United States Geological Survey, 1966.

Allen, William B., Hahn, Glenn W., and Tuttle, Curtis R. Geohydrological Data for the Upper Pawcatuck River Basin, Rhode Island. Rhode Island Goological Bulletin No. 13. Providence: United States Geological Survey, 1963.

Barlowe, Raleigh. Land Resource Economics. Finglewood Cliffs: Prentice-HaII, Inc., 1958.

Bosch, H. M., Rosenfield, A. B., Shipman, H. R., and Woodward, R. I. "Methemoglobinemia and Minnesota Well Supplites," Journal of the American Water Works Association, 42 (July, 1950).

Campenni, L. G. "Synthetic Detergents in Ground Waters-Part I," Water and Sewage Works, 108 (1961).

Comprehensive Community Plan, South Kingstown, Rhode Island. Providence: Rhode Island Development Council, January, 1965 .

Engineering News-Record. New York: McGraw-Hill, December 18, 1969 .

Farragut, Paul Robert. "Economics of Use and Distribution of Water in Rhode Island." Unpublished Master's thesis, Department of Food and Resource Economics, University of Rhode Island, 1965.

Feasibility of Development of Water Supply Resources of Rhode Island. Boston: Hetcalf \& Eddy, Engineers, August, 1957.

Flynn, J.M., Andreoli, Aldo, and Guerrera, A. A. "Study of Synthetic Detergents in Ground Water," Journal of the American Water Works Association, 50 (December, 1958).

Griffin, A. E. "Problems Caused by Manganese in Water Supplies," Journal of the American Water Works Association, 50 (1958).

Harris, B. K., and Odland, T. E. Rhode Island Weather. Bulletin of the R.I. Agricultural Experiment station. Kingston: Rhode Island Agricultural Experiment Station, 1948 . 
Intergovernmental Responsibilities for Water Supply and Sewage Disposal in Metropolitan Areas. Washington: Advisory Commission on Intergovernmental Relations, 1962.

Jeffrey, Arthur D. Economics of Water Supply in Rhode Is Iand. Misc. Pub. 62. Kingston: Rhode Island Agricultural Experiment Station, July, 1966.

Kelly, S., Winsser, J., and Winkelstein, W. "Polionyclitis and Other Fnteric Viruses in Sewage," American Journal of Public Health, 47 (January, 1957).

Lang, S. M. Appraisal of the Ground Water Reservoir Areas in Rhode Island. Rhode Island Goological Bulletin No. II. Providence: United States Geological Survey, 1961.

MacKichan, K. A. Estimated Use of Water in the United States, 1950. U.S. Geological Survey Circular 115. Washington: United States Geological Survey, 1951.

MacKichan, K. A. "Estimated Use of Water in the United States, 1955," Journal of the American Water Works Association, $49(1957)$.

MacKichan, K. A., and Kammerer, J. C. Estimated Use of Water in the United States, 1960. U.S. Geological Survey Circular 456. Washington: United States Geological Survey, 1961 .

McGuiness, C. I. The Role of Ground Water in the National Water Situation. Geological Survey Water Supply Paper 1000. Washington: United States Geological Survey, 1963.

Performance of Urban Functions: Local and Areawide. Information Report No. M-21 Revised. Wáshington: Advisory Commission on Intergovermmental Relations, September, 1963.

Preliminary Plan for Public Water Supply and Distribution. Unpublished Report. Providence: Rhode Island Statewide Comprehensive Transportation and Land Use Planning Program, 1969.

Report of the Governor's Task Force on Water Resource Planning. Providence: Governor!s Task Force on Water Resource Planning, 1967.

Report on the Investigation of Travel of Pollution. Sacramento: California state Water Pollution Control Board, 1954.

Report on Waste Water Collection and Disposal Facilities for the lown of Narragansett, Rhode Island. Providence: Charles A. Maguire \& Associates, Engineers, 1968. 
Report to the South Kingstown, Phode Island Planning Board Upon Sewage Facilities Required in the Wakefield peacedale Area. Boston: Metcalf \& Eddy, Engineers, 1958.

Report to the Water Resources Coordinating Board, State of Rhode Island, on a Development Plan for the Water supply Resources of Rhode Island. Boston: Metcalf \& Eddy, Engineers, 1967 .

Rhode Island City and Town Monographs, Ereter. Providence: Rhode Island Development Council, October, 1968.

Rhode Island Department of Health. Personal interview with Mr. John Glifford, Division of Water Supply Control. July 23, 1969.

Tasis Group $2450 \mathrm{R}$. "Survey of Ground Water Contamination and Waste Disposal Practices," Journal of the American Water Works Association, 52 (November, 1960).

Todd, David Keith. Ground Water Hydrology. New York: John Wiley and Sons, Inc., 1959.

University of Rhode Island. Telephone interview with Mir. Huet, Department of Institution Research. August I, 1969.

U.S. Congress, Senate, Select Committee on National Water Resources. Water Resource Activities in the United States: Future Water Requirements for Municipal Use. Committee Print No. 7. 86th Cong., 2d Sess., 1960.

J.S. Congress, Senate, Select Committee on National Water Resources. Water Resource Activities in the United States: Water Supply and Demand. Comittee Print No. 32. 86 th Cong., 2d Sess., 1960.

U.S. Federal Inter-Agency River Basin Committee. Proposed Practices for Economic Analysis of River Basin Projects. Washington: United States Government Printing Office, 1962 .

U.S. Public Health Service. Drinking Water Standards. Public Health Service Publication 956. Washington: United States Government Printing Office, 1962.

Walton, Graham. "ABS Contamination of Water Resources," Journal of the American Water Works Association, 52 (November, 1960).

Water in Industry. New York: National Association of Manufacturers, (n.d.).

A Water Resources Program for Rhode Island. Water Resources Memorandum No. 3. Providence: Rhode Island Development Council, 1954 . 
APPENDIX

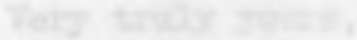

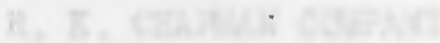

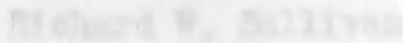




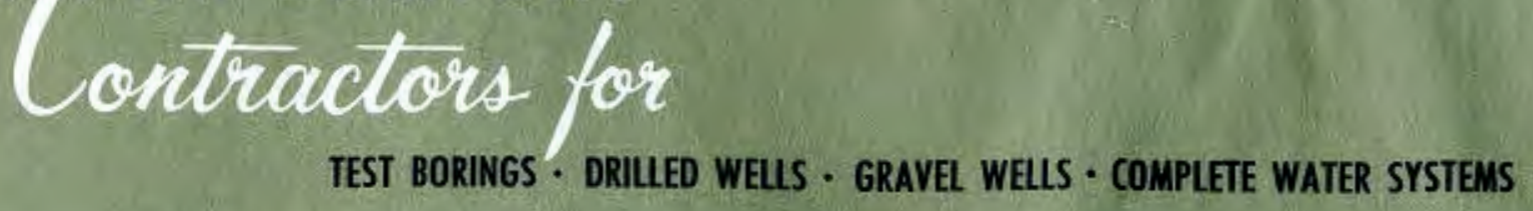

August 8, 1969

Professor Arthur D. Jeffrey

University of Thode Island

Kingston, Rhode Island 02881

Dear Sir:

We acknowledge your letter of July 29, 1969, referring to an estimate of the probable initial development costs associated with a 25 M.G.D. well development in the Epper Pawcatuck River Basin in Southern Rhode Island, obtained by Mr. Paul Farragut.

We would advise adding 20 per cent to the 1965 estimate.

Very truly yours,

R. E. CHARMAN COMPANY



RWS: je

Richard $W$. Sallivan 


\section{RHODE ISLAND DEPARTMENT OF HEALTH \\ Room 335, State Office Building SUMMARY SHERT}

1. Sample represents water safe at time of collection.

2. Sample represents water safe at time of collection but traces of harmless contamination are present. If the natural purification of the water feeding the supply does not change the supply will remain safe, but a single analysis cannot guarantee this.

3. Sample represents water safe at time of collection but traces of harmless contamination are present. The traces of contamination are too pronounced to allow assurance that the water will remain safe.

4. Conditions are such that it is doubtful if the supply can be made satisfactory. Another source of supply should be sought. (a) Connection with the available public supply would be advisable.

6. Bacterial results indicate such a high degree of pollution that the water must be reported unsafe.

7. Bacterial results satisfactory.

8. Baeterial results are somewhat too high to permit considering the water entirely satisfactory for bathing. Submit another sample.

8. (a) The unsatisfactory analysis may be due to the newness of the well. After considerable pumping, the quality of the water may improve.

9. Samples unsatisfactory due to the presence of residual chlorine. Pump to waste until free of odor of chlorine and resubmit samples.

10. Chemical results of sanitary significance are: (a) Satisfactory. (b) Fairly satisfactory. (c) Suggestive of some pollution. (d) Indicative of pollution to a degree that makes it necessary to consider the water unsafe. (e) Indicative of salt water seepage. (f) The presence of synthetic detergent which provides additional evidence of sewage pollution. $(\mathrm{g})$ The presence of synthetic detergent which indicates a relationship between sewage and the well. The safety of the water is not, as yet, affected; it should be checked occasionally.

11. Physical characteristics are: (a) Good. (b) Fair. (c) Poor. 
12. Iron treatment would improve physical quality and eliminate staining due to high iron present.

14. It is possible that quality of the water might be improved by taking the following steps: pump well dry, remove any foreign matter from well, scrub inside of casing, disinfect as in item 14a.

14(a). We would advise chlorinating well, pump, and piping system as follows: Get (at grocery store) 1 pint of chiorine bleach solution ( $5.25 \%$ chlorine) or a proportionately larger amount of weaker solution; pour this solution into the well; operate the pump until the piping system is full of chlorinated water from the well; allow the chlorinated water to remain in the well and piping system overnight; then pump the water to waste until no odor of chlorine is detected. After allowing time for conditions to stabilize, arrange for another analysis.

14(b). Chlorination of well should take place after recommended cleaning and repairing have been completed. Chlorination alone is not sufficient.

15. The following improvements are necessary:

(a) A watertight cover should be provided for the well. A sanitary seal or equivalent should be installed on all drilled wells.

(b) The surface of the ground at the source of supply should be banked with fine earth or concrete to prevent surface wash from entering top of well casing.

(c) Dug well should be filled in with clean clay to grade.

(d) Bucket or open top pump should be replaced by a closed top force pump.

(e) Well casing should be made watertight at least six inches above and ten feet below ground level.

16. After carrying out the suggested improvements and allowing a time for conditions to stabilize, arrange for a check analysis.

18. The contamination or pollution of the supply may be due to its proximity to: (a) Cesspool or other sewage seepage system. (b) Privy. (c) Barn. (d) Manure pile. (e) Chicken or animal yard. ( $f$ ) Sewer or drain (if leaky or discharging). (g) Fertilized garden. (h) Brook, pond or river, or to: (i) Insufficient protection against contamination getting in at top of supply. ( $\mathrm{j}$ ) Handling of receptacles in drawing water. (k) Open top hand pump which may receive and harbor pollution. (1) Waste water spilling from pump. (m) Drainage in well pit.

19. Pool water below becteriological standard because:

(a) $35^{\circ} \mathrm{C}$ plate count exceeds 200 bacteria per mz. (b) Coliform bacteria are present.

20. The available chlorine content of the pool water at the time the samples were collected was below standard because available chlorine was: (a) Absent. (b) Too low. (c) Too high. 
21. A minimum of $0.4 \mathrm{ppm}$ of free chlorine must be present in the pool water when the pool is open for use. A minimum of $1.0 \mathrm{ppm}$ of free chlorine must be maintained in fill and draw type wading pools.

22. $\mathrm{pH}$ of the pool water when the samples were collected was: (a) Too low. (b) Too high.

23. pH mast not be lower than 7.2 nor higher than 8.4 when the pool is open for use.

25. Physical quality of the pool water was unsatisfactory at the time the sample was collected. This indicates poor maintenance, failure of the filtering system, or bather loading in excess of design capacity. Appropriate action must be taken promptly.

31. The privy should be located not less than 65 feet from the well, and not on higher ground than the well.

3I(a). The sewage seepage system should be located not less than 100 feet from the well and not on higher ground than the well. (This distance may not be adequate under all conditions; a greater distance should be provided where possible).

31(b). Location of well in basement of building is unsafe.

32. Information on the survey sheet shows that lead pipe is present in your water piping system; a test for lead should be made. Special bottles for this purpose must be obtained at room 335 state office Building.

33. More definite judgment of the quality of the water cannot be made until:

(a) the information requested on the survey sheet is supplied in full.

(b) a sample for a chemical analysis is submitted.

(c) a sample for a bacteriological analysis is submitted.

34. Nitrates so high that water should not be consumed by infants due to possibility of development of methemoglobinemia (blue baby).

35. Bluish green staining of plumbing fixtures is usually due to the presence of copper dissolved from the piping system. Copper should not be in excess of $1.0 \mathrm{ppm}$. 
Summary of Water Quality Analysis for Individual

Private Wells in the Town of South Kingstown

Test \# Date of

Summary of
Analysis 1

\begin{tabular}{rrl}
\hline 1 & $3 / 18 / 69$ & $1,11 b, 15 e, 31 a$ \\
2 & $8 / 19 / 68$ & $1,11 a, 31 a$ \\
3 & $5 / 13 / 68$ & $3,11 a, 31 a$ \\
4 & $4 / 8 / 68$ & $10 \mathrm{a}, 11 a, 31 a, 31 b$ \\
5 & $1 / 21 / 69$ & $3,11 b, 15 a, 34,4 a$ \\
6 & $8 / 21 / 68$ & $2,11 c, 31 a$ \\
7 & $7 / 30 / 68$ & 6,4 \\
8 & $12 / 21 / 68$ & $6,10 b, 14 a, 34,33 a$ \\
9 & $4 / 9 / 68$ & $1,11 a$ \\
10 & $3 / 26 / 68$ & $1,11 a, 15 e, 31 a$ \\
11 & $3 / 25 / 68$ & 9 \\
12 & $12 / 10 / 68$ & $3,11 a, 15 a, 15 e, 31 a$ \\
13 & $10 / 9 / 68$ & $6,8 a, 10 a, 11 a, 14 a$ \\
14 & $4 / 9 / 69$ & $1,11 a, 15 e$ \\
15 & $7 / 29 / 68$ & $10 a, 11 a, 33 c$ \\
16 & $8 / 14 / 68$ & $1,11 a, 31 a$ \\
17 & $1 / 22 / 68$ & $1,31 a$ \\
18 & $4 / 16 / 68$ & $1,33 a$ \\
19 & $4 / 17 / 68$ & $1,11 a, 15 e$ \\
20 & $8 / 28 / 68$ & $1,11 a, 31 a$ \\
21 & $7 / 15 / 68$ & $1,11 a, 15 a, 15 b, 15 e$ \\
22 & $8 / 21 / 68$ & $3,11 b, 31 a$ \\
23 & $5 / 14 / 69$ & $1,11 b, 31 a$ \\
24 & $1 / 15 / 68$ & $3,11 a, 31 a$ \\
25 & $9 / 25 / 68$ & $6,10 a, 14 a, 15 e, 31 a$ \\
26 & $4 / 30 / 69$ & $3,11 c, 15 e, 31 a$ \\
27 & $4 / 29 / 69$ & $1,11 a, 31 b$ \\
28 & $2 / 14 / 68$ & $6,10 a, 11 a, 11 a$ \\
29 & $11 / 12 / 68$ & $6,10 a, 10 f, 11 b, 14 a, 31 a$ \\
30 & $5 / 20 / 68$ & $1,11 a, 15 a, 31 a$ \\
& &
\end{tabular}

INumbers refer to numbered items on the Rhode Island Department of Health Summary Sheet. 
pest \# Date of

Summary of

Test

Analysis

\begin{tabular}{rrl}
\hline 31 & $4 / 16 / 68$ & $7,33 \mathrm{a}$ \\
32 & $11 / 12 / 68$ & $6,10 \mathrm{a}, 11 \mathrm{c}, 14 \mathrm{a}$ \\
33 & $2 / 28 / 69$ & $1,11 \mathrm{a}, 31 \mathrm{a}$ \\
34 & $5 / 7 / 68$ & $2,11 \mathrm{c}, 8 \mathrm{a}, 15 \mathrm{e}$ \\
35 & $3 / 26 / 68$ & $1,11 \mathrm{~b}$ \\
36 & $5 / 6 / 68$ & $1,11 \mathrm{a}, 15 \mathrm{a}, 15 \mathrm{~b}, 31 \mathrm{a}, 31 \mathrm{~b}$ \\
37 & $3 / 26 / 68$ & $1,11 \mathrm{~b}, 15 \mathrm{e}, 31 \mathrm{a}$ \\
38 & $10 / 21 / 68$ & $6,14 \mathrm{a}, 31,31 \mathrm{~b}, 33 \mathrm{~b}$ \\
39 & $8 / 14 / 68$ & $1,11 \mathrm{a}$ \\
40 & $4 / 30 / 68$ & $6,10 \mathrm{~b}, 11 \mathrm{a}, 14 \mathrm{a}, 14 \mathrm{~b}, 15 \mathrm{~b}, 15 \mathrm{e}$ \\
41 & $10 / 21 / 68$ & $6,14 \mathrm{a}, 31,31 \mathrm{~b}, 33 \mathrm{~b}$ \\
42 & $8 / 28 / 68$ & $1,11 \mathrm{a}$ \\
43 & $3 / 27 / 68$ & $1,10 \mathrm{e}, 11 \mathrm{a}, 15 \mathrm{a}, 15 \mathrm{e}, 31 \mathrm{a}$ \\
44 & $4 / 2 / 68$ & $10 \mathrm{~d}, 10 \mathrm{f}, 11 \mathrm{c}, 15 \mathrm{e}, 31 \mathrm{a}, 4 \mathrm{a}$ \\
45 & $4 / 16 / 68$ & $7,33 \mathrm{a}$ \\
46 & $5 / 7 / 69$ & $1,11 \mathrm{a}, 31 \mathrm{a}, 4 \mathrm{a}$ \\
47 & $3 / 27 / 68$ & $3,10 \mathrm{a}, 11 \mathrm{a}, 15 \mathrm{a}, 31 \mathrm{a}$ \\
48 & $7 / 24 / 68$ & $1,11 \mathrm{a}, 15 \mathrm{a}, 31 \mathrm{a}$ \\
49 & $9 / 11 / 68$ & $1,11 \mathrm{a}, 15 \mathrm{a}$ \\
50 & $7 / 23 / 68$ & $3,11 \mathrm{~b}, 15 \mathrm{e}$ \\
51 & $12 / 17 / 68$ & $1,11 \mathrm{a}, 15 \mathrm{e}, 31 \mathrm{a}$ \\
52 & $4 / 16 / 68$ & $7,33 \mathrm{a}$ \\
53 & $7 / 10 / 68$ & $1,11 \mathrm{a}, 31 \mathrm{a}$ \\
54 & $4 / 10 / 68$ & $1,11 \mathrm{a}, 31 \mathrm{a}$ \\
55 & $11 / 25 / 68$ & $10 \mathrm{~d}, 10 \mathrm{f}, 11 \mathrm{~b}, 15 \mathrm{~b}, 15 \mathrm{e}, 31 \mathrm{a}, 31 \mathrm{~b}, 4$ \\
56 & $7 / 16 / 68$ & $6,10 \mathrm{~b}, 11 \mathrm{a}, 15 \mathrm{e}, 31 \mathrm{a}, 4$ \\
57 & $8 / 6 / 68$ & $1,11 \mathrm{a}, 15 \mathrm{e}, 31 \mathrm{a}$ \\
58 & $1 / 13 / 69$ & $10 \mathrm{~d}, 11 \mathrm{c}, 31 \mathrm{a}, 34$ \\
59 & $5 / 14 / 68$ & $1,11 \mathrm{~b}, 33 \mathrm{a}$ \\
60 & $5 / 11 / 68$ & $3,11 \mathrm{~b}, 31 \mathrm{a}, 33 \mathrm{a}$ \\
61 & $5 / 14 / 68$ & $2,11 \mathrm{~b}, 33 \mathrm{a}$ \\
63 & $5 / 14 / 68$ & $3,11 \mathrm{~b}, 33 \mathrm{a}$ \\
64 & $2 / 12 / 68$ & $1,11 \mathrm{a}, 15 \mathrm{e}$ \\
& $4 / 2 / 68$ & $1,11 \mathrm{a}, 15 \mathrm{e}$ \\
\hline 3 & &
\end{tabular}


Test \# Date of Test

Surmary of

Analysis

65

66

67

68

69

70

71

72

73

74

75

76

77

78

79

80

81

82

83

84

85

86

87

88

89

90

91

92

93

94

95

96

97

98
$6 / 2 / 69$

$7 / 15 / 68$

$9 / 10 / 68$

$9 / 4 / 68$

$3 / 27 / 68$

4/15/68

2/12/69

$3 / 25 / 68$

$4 / 23 / 68$

$8 / 74 / 68$

$10 / 28 / 68$

$6 / 18 / 68$

$5 / 20 / 68$

$10 / 21 / 68$

$7 / 2 / 68$

$8 / 5 / 68$

$6 / 12 / 68$

$2 / 11 / 69$

$11 / 22 / 68$

$6 / 4 / 69$

$4 / 7 / 69$

$3 / 26 / 68$

$4 / 2 / 68$

4/22/69

$1 / 22 / 68$

$8 / 6 / 68$

$11 / 28 / 68$

$3 / 25 / 68$

$8 / 5 / 68$

$8 / 7 / 68$

$11 / 14 / 68$

$11 / 1 / 68$

$2 / 5 / 68$

$2 / 5 / 68$
$1,112,31 a$

$6,100,11 a, 14 a, 14 b, 15 a, 15 e, 31 a$

$3,108,112$

$1,11 a, 150,31 a, 4 a$

$1,11 a, 15 e, 31 a$

$10 \mathrm{~d}, 10 \mathrm{f}, 11 \mathrm{~b}, 15 \mathrm{a}, 150,31 \mathrm{~b}$

$2,11 b, 15 a, 31 a$

3

$6,10 a, 11 a, 14 a, 15 e, 31 a, 31 b$

$1,11 \mathrm{a}, 15 \mathrm{~b}, 15 \mathrm{e}, 31 \mathrm{a}$

1,1la

10d, 10f, 11c, $31 \mathrm{a}$

lod, 10f, Ilc, 3la, 4

$7,31,31 \mathrm{a}, 33 \mathrm{~b}$

$6,10 a, 10 e, 11 a, 14,14 b, 31 a, 4 a$

$2,11 a, 31 a$

$2,11 a, 150,31 a$

$1,11 \mathrm{a}, 15 \mathrm{e}$

$1,110,150$

$1,11 b, 15 a, 15 e, 31 a$

$6,10 a, 11 a, 14 a, 15 a$

$3,11 \mathrm{~b}$

$1,11 a, 31 a, 31 b$

3,11a, 15a, $15 \mathrm{e}$

$3,11 a$

$1,11 \mathrm{c}, 12$

$3,11 b$

$1,11 \mathrm{c}$

$3,11 b$

$6,10 \mathrm{a}, 11 \mathrm{a}, 14,14 \mathrm{a}, 15 \mathrm{e}$

1, 11a

$1,11 a$

$6,10 c, 11 a, 14 a, 14 b, 15 a, 31 b, 4$

$6,10 \mathrm{~b}, 11 \mathrm{a}, 14 \mathrm{a}, 14 \mathrm{~b}, 15 \mathrm{a}, 15 \mathrm{e}$ 


\begin{tabular}{lrl} 
Test \# & $\begin{array}{c}\text { Date of } \\
\text { Test }\end{array}$ & \multicolumn{1}{c}{$\begin{array}{c}\text { Summary of } \\
\text { Analysis }\end{array}$} \\
\hline 99 & $7 / 16 / 68$ & $6,10 \mathrm{~d}, 11 \mathrm{c}, 14 \mathrm{a}, 14 \mathrm{~b}, 15 \mathrm{a}, 15 \mathrm{e}, 31,31 \mathrm{a}, 15$ \\
100 & $8 / 5 / 68$ & $1,11 \mathrm{a}, 31 \mathrm{a}$ \\
101 & $8 / 5 / 68$ & $3,11 \mathrm{~b}, 31 \mathrm{a}$ \\
102 & $4 / 16 / 68$ & $7,33 \mathrm{a}$ \\
103 & $1 / 9 / 68$ & $3,11 \mathrm{a}, 31 \mathrm{a}$ \\
104 & $11 / 27 / 68$ & $1,11 \mathrm{a}, 4 \mathrm{a}$ \\
105 & $9 / 17 / 68$ & $3,11 \mathrm{~b}, 15 \mathrm{e}, 4 \mathrm{a}$ \\
106 & $5 / 31 / 68$ & $6,10 \mathrm{c}, 11 \mathrm{~b}, 14,14 \mathrm{a}, 14 \mathrm{~b}, 15 \mathrm{~b}, 15 \mathrm{e}, 31 \mathrm{a}$ or 4 \\
107 & $5 / 6 / 68$ & $6,10 \mathrm{~b}, 11 \mathrm{a}, 14,14 \mathrm{a}, 34$ \\
108 & $5 / 9 / 68$ & $3,11 \mathrm{c}, 15 \mathrm{e}$ \\
109 & $7 / 10 / 68$ & $6,10 \mathrm{c}, 11 \mathrm{~b}, 14 \mathrm{a}, 15 \mathrm{a}, 31 \mathrm{a}$ \\
110 & $7 / 3 / 68$ & $6,10 \mathrm{a}, 11 \mathrm{a}, 14 \mathrm{a}, 15 \mathrm{e}$ \\
111 & $4 / 10 / 68$ & $6,10 \mathrm{a}, 11 \mathrm{~b}, 14 \mathrm{a}, 15 \mathrm{~b}, 15 \mathrm{e}, 31 \mathrm{a}$ \\
112 & $7 / 10 / 68$ & $2,11 \mathrm{~b}, 31 \mathrm{a}$ \\
113 & $5 / 27 / 68$ & $1,10 \mathrm{e}, 11 \mathrm{a}, 31 \mathrm{a}$ \\
111 & $6 / 18 / 68$ & $1,11 \mathrm{a}, 31 \mathrm{a}$ \\
115 & $7 / 23 / 68$ & $1,11 \mathrm{a}, 31 \mathrm{a}$ \\
116 & $6 / 3 / 69$ & $1,11 \mathrm{a}, 31 \mathrm{a}$ \\
117 & $9 / 10 / 68$ & $1,11 \mathrm{a}, 31 \mathrm{a}, 31 \mathrm{~b}, 4 \mathrm{a}$
\end{tabular}


Summary of Water Quality Analysis for Individual

Private Wells in the Town of Exeter

Test \#

Date of

Test

Summary of

1

2

3

4

5

6

7

8

9

10

11

12

13

14

15

16

17

18

19

20

21

22

23

24

25

26

27

28

29
$4 / 14 / 69$

$10 / 23 / 68$

$12 / 3 / 68$

$7 / 31 / 68$

$1 / 14 / 69$

$1 / 20 / 69$

$6 / 19 / 68$

$6 / 11 / 69$

$9 / 11 / 68$

$5 / 7 / 68$

$6 / 17 / 69$

$8 / 7 / 68$

$6 / 24 / 69$

$8 / 21 / 68$

$7 / 8 / 68$

$11 / 20 / 68$

$9 / 24 / 68$

$6 / 23 / 69$

$3 / 17 / 69$

$8 / 6 / 68$

$7 / 29 / 68$

$3 / 4 / 69$

$7 / 30 / 68$

$9 / 17 / 68$

$1 / 6 / 69$

$3 / 25 / 68$

$5 / 27 / 69$

$2 / 18 / 69$

$12 / 11 / 68$
$1,11 \mathrm{c}, 15 \mathrm{a}$

2,11a

2, IIc

1, Ila, 31a

$6,10 b, 11 a, 14 a, 15 e, 31 a, 34$

$6,10 \mathrm{c}, 11 \mathrm{a}, 14 \mathrm{a}, 14 \mathrm{~b}, 15 \mathrm{a}, 15 \mathrm{c}, 34$

$1,11 a$

2, 11a, 15a

$10 d, 10 f, 11 c, 15 a, 15 e, 31 a$

$1,15 \mathrm{~d}$

1,1la

I, Ila

$6,10 a, 11 a, 119,150$

$1,11 a$

$6,10 a, 11 c, 14 a, 31 a$

$1,11 \mathrm{~b}$

$6,10 \mathrm{~d}, 110,14,14 \mathrm{a}, 15 \mathrm{a}, 15 \mathrm{e}, 31 \mathrm{a}$

$1,11 a, 15 a$

$1,110,15 a, 31 a$

$1,11 \mathrm{c}$

$1,11 a, 31 a$

$1,11 b$

$3,11 \mathrm{c}$

$3,11 a$

$6,10 b, 11 a, 14 a, 15 e, 31 a$

$1,11 \mathrm{a}, 15 \mathrm{~b}, 31 \mathrm{a}$

$1,11 b, 31 a$

$1,11 a, 15 a$

$1,11 b, 15 a, 31 a$

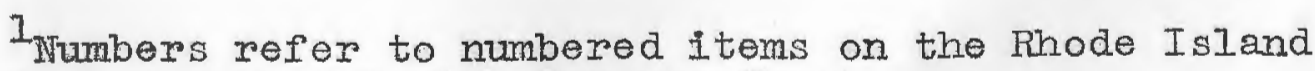
Department of Health Summary Sheet. 


\begin{tabular}{lll} 
Test \# & $\begin{array}{c}\text { Date of } \\
\text { Test }\end{array}$ & \multicolumn{1}{c}{$\begin{array}{c}\text { Summary of } \\
\text { Analysis }\end{array}$} \\
\hline 30 & $1 / 6 / 69$ & $1,11 \mathrm{~b}$ \\
31 & $1 / 6 / 69$ & $3,11 \mathrm{~b}, 15 \mathrm{a}, 15 \mathrm{e}, 34$ \\
32 & $5 / 1 / 68$ & $1,11 \mathrm{c}, 31 \mathrm{a}$ \\
33 & $1 / 24 / 68$ & $1,31 \mathrm{a}$ \\
34 & $4 / 30 / 68$ & $1,11 \mathrm{a}$ \\
35 & $9 / 4 / 68$ & $6,10 \mathrm{a}, 11 \mathrm{~b}, 14 \mathrm{a}, 15 \mathrm{~b}, 31 \mathrm{a}$ \\
36 & $12 / 3 / 68$ & $1,11 \mathrm{c}$ \\
37 & $8 / 21 / 68$ & $6,10 \mathrm{c}, 11 \mathrm{a}, 14 \mathrm{a}, 14 \mathrm{~b}, 15 \mathrm{a}, 15 \mathrm{e}$ \\
38 & $6 / 25 / 69$ & $1,11 \mathrm{a}$ \\
39 & $7 / 11 / 68$ & $2,11 \mathrm{a}, 31 \mathrm{a}$ \\
40 & $4 / 29 / 68$ & $1,11 \mathrm{a}$
\end{tabular}

